\title{
O eclipse do Principal: apontamentos sobre as mudanças de hierarquias entre os indígenas do Grão-Pará e os impactos no controle da sua mão de obra (décadas de 1820 e 1830)
}

\author{
André Roberto de Arruda Machado*
}

\section{RESUMO}

Este artigo parte do quase desaparecimento de citaçôes à figura dos Principais dos "indígenas avilados" na documentação sobre o Grão-Pará, nas décadas de 1820 e 1830 . O esvaziamento, a partir da Carta Régia de 1798, de funçôes centrais dos Principais na política de recrutamento de máo de obra e dos descimentos, somada à acelerada integraçáo das antigas aldeias às vilas e povoados, parece ter resultado na primeira metade do XIX em uma organização social distinta daquela marcada pelo Diretório. Por um lado, esses aspectos devem ser considerados para refletir sobre as identidades indígenas que, apesar de um cenário adverso, mantêm-se bastante marcadas na sociedade desta província. Também como resultante das mudanças na organizaçáo do trabalho indígena, é patente o fortalecimento dos oficiais de Milícias de Ligeiros como atores políticos. Como se pretende demonstrar, esses indivíduos passam a ter uma ação destacada na província, sempre marcada pela oposição aos grupos identificados como liberais. Por fim, pretende-se ainda fazer alguns apontamentos sobre o papel das câmaras em tentativas de resguardar os indígenas de abusos na utilizaçáo da sua mão de obra. De forma preliminar, interroga-se se nestes espaços ainda se manteve preservada a voz das lideranças indígenas.

Palavra-chave: indígenas; Principais; Grão-Pará, Império do Brasil, mão de obra.

\section{ABSTRACT}

This paper stems from the near disappearance of references to the Principais of the indigenas avilados (Natives living in colonial villages) in the documentation about the province of

\section{DOI- http://dx.doi.org/10.1590/2237-101X0183408}

Artigo recebido em 26 de novembro de 2016 e aprovado para publicação em 20 de janeiro de 2017.

*Professor na Universidade Federal de São Paulo, Guarulhos - SP, Brasil. E-mail: andremachados@yahoo.com.br. Agradeço aos meus orientandos Evelyn Lauro, Samuel Ferreira e Amanda Carvalho que localizaram alguns dos documentos citados. Uma versão preliminar e reduzida deste artigo foi apresentada no $27^{\circ}$ Encontro Nacional de História e publicado em seus Anais Eletrônicos. Agradeço as críticas e os comentários que permitiram reformular o texto e incorporar novos documentos. 
O EClipse do PRINCIPAL: APONTAMENTOS SOBRE AS MUdANÇAS DE HiERARQUias ENTRE OS INDÍGENAS DO Gráo-Pará e os impactos no CONTROLE da SUA Mão de obra (DÉCADAS DE I 820 E I 830 )

Grão-Pará, in the 1820s and 1830s. By reducing the role of the Principais in workforce recruitment and descimentos (the transfer of Native villages to colonial towns), the Royal Charter of 1798 added to the increased integration of old Native villages to colonial towns. In the first half of the nineteenth century, the result appears to have been a different social organization from the one established by the Diretorio. On one hand, these aspects should be taken into account when examining the issue of Native identities, which, in spite of an adverse scenario, remained quite clear in the provincial society. On the other hand, changes in Native labor organization also strengthened officials of the Milícias de Ligeiros. As political actors, they started having a leading role in the province, always marked by the opposition to groups identified as liberal. Finally, this paper includes some notes on the attempts of city councils to protect Natives from abuses. In a preliminary way, we examine whether Native voices were still preserved in such spaces.

Keywords: Natives; Principal; Grão-Pará; Empire of Brazil; workforce.

\section{RESUMEN}

Este artículo parte de la casi desaparición de citaciones a la figura de los Principales de los indígenas avilados (reunidos en pueblos coloniales) en la documentación sobre el Grão-Pará, en las decadas de 1820 y 1830 . El vaciamiento, a partir de la Carta Regia de 1798, de las funciones centrales de los Principales en la política de reclutamiento de mano de obra y de los descimentos, sumado a la integración acelerada de antiguos pueblos indigenas a las ciudades y pueblos coloniales, parece haber resultado en la primera mitad del siglo XIX en una organización social distinta de aquella definida por el Directorio. De un lado, estos aspectos deben ser considerados para reflexionar sobre las identidades indígenas que, a pesar de un escenario adverso, se mantienen bastante marcadas en la sociedad de esta província. También como resultado de los cámbios en la organización de la labor indígena, está claro el fortalecimiento de los oficiales de las Milicias de Ligeiros como actores políticos. Se pretiende demonstrar que estos individuos pasan a tener una acción destacada en la província, siempre marcada por la oposición a los grupos identificados como liberales. Finalmente, se pretiende también hacer alguns apuntes sobre el papel de las cámaras en sus intentos de proteger los indígenas de los abusos laborales. De manera preliminar, se cuestiona si, en estos espacios, se preservó la voz de los liderazgos indígenas.

Palabras clave: indígenas; Principales; Grão-Pará; Império de Brasil; mano de obra. 
O ECLIPSE do PRINCIPAL: APONTAMENTOS SOBRE AS MUdANÇAS DE HIERARQUias ENTRE OS INDÍGENAS DO

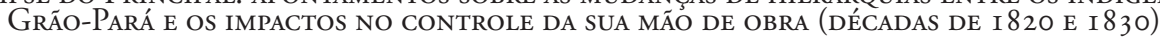

\section{Hierarquias e controle do trabalho: um mundo em mudanças}

Ao lidar com praticamente qualquer conjunto documental sobre a província do Grão-Pará, nas décadas de 1820 e 1830, certamente o leitor se deparará com mençóes aos indígenas e, especialmente, sobre questôes relacionadas com o controle da mão de obra desses indivíduos. Mesmo em códices que misturam assuntos diversos, tal como está organizado o Arquivo Público do Pará, é quase certo que o pesquisador encontrará em uma busca aleatória as temáticas mencionadas. Tal dimensão deixa evidente a importância dos indígenas nessa sociedade.

Tendo isso em vista, este artigo parte de duas constataçôes complementares, após mais de um década realizando atividades de pesquisa e de orientação, nas quais foi possível entrar em contato com um conjunto de milhares de documentos sobre o Pará nas décadas de 1820 e $1830 .{ }^{1}$ A primeira dessas constataçóes é que neste período, das décadas de 1820 e 1830, praticamente não há citaçôes aos Principais ${ }^{2}$ indígenas nas fontes, algo que é evidentemente contrastante com a realidade encontrada no período anterior: marcadamente no Diretório Pombalino, ${ }^{3}$ novas pesquisas têm mostrado o grande protagonismo dessas lideranças. Ressalte-se aqui, antes de mais nada, que o que se tem em vista neste artigo são os Principais dos "índios avilados", para usar um termo do período, aqueles que viviam nas vilas e povoados. A segunda constatação é o aumento crescente da importância dos oficiais de Milícias de Ligeiros, ${ }^{4}$ no mesmo período. À medida que são cada vez mais citados nos trâmites e nas dis-

\footnotetext{
${ }^{1}$ Entre outros, são exemplos de resultados dessas pesquisas: MACHADO, André Roberto de A. A quebra da mola real das sociedades: a crise política do Antigo Regime Português na província do Grão-Pará (1821-25). 1. ed. São Paulo: Hucitec/Fapesp, 2010; MACHADO, André Roberto de A. O Conselho Geral da Província do Pará e a definição da política indigenista no Império do Brasil (1829-31). Almanack, v. 10, p. 181-237, 2015; LAURO, Evelyn Ariane. Festas públicas e ritos cívicos na incorporaçáo do Pará ao Estado Nacional Brasileiro (1826 1831). Trabalho de Conclusão de Curso (Graduação em História) — Universidade Federal de São Paulo, 2016; MALLORGA, Bruna Valença. As facçôes da Igreja Católica no Gräo-Pará e na Corte na disputa pelo controle do Estado (1826-1831). Trabalho de Conclusão de Curso (Graduaçáo em História) - Universidade Federal de São Paulo, 2016; FERREIRA, Samuel Rocha. Trabalho compulsório indígena na província do Pará: 1826-31. Trabalho de Conclusão de Curso (Graduação em História) — Universidade Federal de São Paulo, 2016.

${ }^{2}$ De maneira sintética, os Principais eram indígenas que exerciam a função de chefia. Essas lideranças já existiam antes da chegada dos europeus, mas sofrem uma profunda reelaboração no contexto colonial no caso de sociedades em contato permanente com os não indígenas. Essa figura será bastante desenvolvida no próximo tópico do artigo.

${ }^{3} \mathrm{O}$ Diretório foi a política indigenista aplicada durante o governo de Pombal, em meados do século XVIII, encerrando sua aplicação no Pará em 1798. Como se verá ao longo do texto, esta política tinha os Principais indígenas como um eixo central.

${ }^{4}$ As Milícias de Ligeiros eram milícias criadas a partir da Carta Régia de 1798, que pôs fim ao Diretório. Com o fim do Diretório, os índios náo estavam mais submetidos à tutela dos Diretores ou a de qualquer outro homem. No entanto, o governo português se preocupou em manter condiçóes para que o recrutamento forçado da mão de obra indígena permanecesse, a despeito da existência dos Diretores. Para isso, criou-se a Milícia de Ligeiros, na qual todos os indígenas que viviam entre os brancos eram obrigatoriamente alistados. Com base nessa lista, todos os indígenas que não pudessem comprovar trabalho contínuo eram obrigados a prestar serviços para particulares ou para o Estado. Isso será desenvolvido ao longo do texto.
} 
O ECLIPSE do PRINCIPAL: APONTAMENTOS SOBRE AS MUdANÇAS DE HIERARQUias ENTRE OS INDÍGENAS DO Gráo-Pará e os impactos no CONTROLE da SUA Mão de obra (DÉCADAS DE I 820 E I 830 )

putas do recrutamento da mão de obra indígena, mais cresce o vulto de suas açôes na política provincial. De maneira complementar, este artigo busca fazer alguns apontamentos sobre as açóes das câmaras das vilas no período, destacadamente aquelas ligadas ao controle da mão de obra dos indígenas. Como algumas dessas medidas das câmaras deixam evidente o esforço por garantir direitos dos indígenas frente às açôes de recrutamento que não respeitavam isençôes ou parâmetros legais, interroga-se se as antigas lideranças dos Principais, aparentemente eclipsadas na documentação, não estariam nessa instituição.

Todas essas questôes estão interligadas a uma preocupação geral: busca-se ter mais clareza de como estavam organizadas as populaçôes indígenas "aviladas" no Pará após a Carta Régia de $1798,{ }^{5}$ tendo como pressuposto que os mecanismos de recrutamento da mão de obra são fatores que interferiam decisivamente na reinvenção dessas comunidades em contato com o mundo dos brancos e, consequentemente, de suas identidades. De modo mais específico, está em questão se o cenário descrito por Maria Regina Celestino de Almeida, para os indígenas aldeados do Rio de Janeiro no século XIX, guarda semelhança com a realidade no Grão-Pará no mesmo período. No caso do Rio de Janeiro, as comunidades indígenas tinham bem demarcado o seu pertencimento às aldeias e sua ligação com as lideranças, o que influía na constituição de uma identidade nova: a de indígena aldeado e não mais as antigas identidades étnicas. ${ }^{6}$ Este ponto de contato com a descrição feita por Almeida é importante para se pensar as identidades no Grão-Pará, já que os "índios avilados", centro deste artigo, em grande parte eram descendentes de populaçôes aldeadas anteriormente ao Diretório, ou trazidas às vilas nesse período, convivendo em um mesmo espaço com diferentes etnias e com lideranças que, apesar de manterem o nome de Principais, já eram uma reinvenção do contato.

Como se verá nas próximas páginas, houve diferenças entre essas realidades e aqui cabe ressaltar como o Grão-Pará e a política indigenista no interior do seu território estiveram inseridas em contextos maiores, primeiro do império português e, posteriormente, do império do Brasil. A principal hipótese deste artigo para a organização social distinta das hierarquias indígenas no Pará, em relação à realidade encontrada por Almeida no Rio de Janeiro, fundamenta-se na aplicação da lei de 1798 em território paraense. Como será mais bem explicado no tópico seguinte, a Carta Régia de 1798 pôs fim ao Diretório Pombalino, tendo grande impacto sobre o poder dos Principais por retirar deles as suas prerrogativas de organização do trabalho dos indígenas. Apesar de Vânia Losada ter identificado no Espírito Santo aplicaçóes da Carta Régia de 1798, isso parece ter sido uma exceção. ${ }^{7}$ De modo geral,

\footnotetext{
${ }^{5}$ A Carta Régia de 1798 é a lei indigenista que póe fim ao Diretório Pombalino, ao menos no Grão-Pará, nos termos descritos acima.

${ }^{6}$ ALMEIDA, Maria Regina Celestino de. Metamorfoses indigenas: identidade e cultura nas aldeias coloniais do Rio de Janeiro. Rio de Janeiro: Arquivo Nacional, 2001.

${ }^{7}$ MOREIRA, Vânia Maria Losada. A serviço do Império e da nação: trabalho indígena e fronteiras étnicas no Espírito Santo (1822-60). Anos 90, v. 17, n. 31, 2010; MOREIRA, Vânia Maria Losada. Índios e império: direitos sociais e agenciamento indígena. Anais da Anpuh, ST 36, 2009.
} 
O ECLIPSE do PRINCIPAL: APONTAMENTOS SOBRE AS MUdANÇAS DE HIERARQUias ENTRE OS INDÍGENAS DO

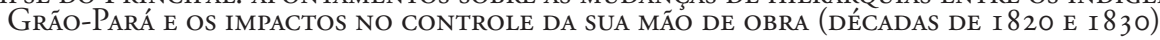

salvo o caso conhecido do Espírito Santo, parece evidente que essa lei teve sua aplicação restrita ao Pará, aliás como afirma Patrícia Sampaio. ${ }^{8}$ Um dos fatos que demonstram isso é que já nas primeiras décadas do império do Brasil é possível encontrar debates no Parlamento a respeito do tratamento aos indígenas em várias províncias que claramente se regulavam pelas normas do Diretório. Além disso, em 1831, quando o senado discutiu e determinou a extinção da Milícia de Ligeiros do Grão-Pará, como se verá uma instituição criada pela lei de 1798 e fundamental no recrutamento de indígenas para o trabalho compulsório, é evidente que quase nenhum senador imaginava do que estava tratando. ${ }^{9}$

A ignorância dos senadores a respeito do que acontecia no Pará em relação aos indígenas demonstra que no império, pelo menos até 1845 , não houve uma política indigenista uniforme, mas uma sobreposição de normas, algumas delas vindas do período colonial, outras definidas por instituiçôes provinciais. Dessa maneira, o que define a política indigenista no império do Brasil até 1845 não é o "vazio legislativo", como afirmou Manuela da Cunha, mas a sobreposição de normas legais. Isso, aliás, não é uma exclusividade da questão indígena. Vários assuntos, muitos deles capitais para o Estado e a sociedade, esperaram décadas até serem regulamentados pelo parlamento no império do Brasil. ${ }^{10}$

É justamente esse caráter sobreposto de normas que torna impossível pensar a política indigenista apenas na letra da lei e, além disso, torna tão diversa a situação desses povos pelas províncias no começo do século XIX. É o embate entre os grupos que permite que uma regra legal se sobreponha às outras. Afinal, regular as relaçóes com os indígenas, em pleno Estado independente, com uma lei colonial como a Carta Régia de 1798 dependeu da força de certos grupos do Pará interessados em manter o controle compulsório da mão de obra. Da mesma forma, é isso que explica o progressivo deslocamento do papel central dos juízes das Câmaras para os oficiais de Milícias de Ligeiros, assunto central deste texto. Por outro lado, é importante ressaltar, ao mesmo tempo que as políticas indigenistas interferem nas sociedades dos "índios avilados" do Pará, as "políticas indígenas" também moldam essas políticas. Afinal, como demonstrei em trabalhos anteriores, os indígenas do Pará se valeram do discurso liberal triunfante a partir das Cortes de Lisboa para reivindicar o papel de cidadãos e o fim do trabalho compulsório imposto pela lei de $1798 .{ }^{11} \mathrm{O}$ resultado dessa ação indígena é um dos elementos não só uma guerra civil entre 1823 e 1825, como também de um progressivo questionamento das normas coloniais que amparavam o trabalho compulsório desses braços. O resultado é que a década de 1830 assistirá mais de uma tentativa das

\footnotetext{
${ }^{8}$ Patrícia Sampaio é provavelmente a historiadora que afirma mais categoricamente que a aplicação da Carta Régia de 1798 se restringiu ao Pará. Veja SAMPAIO, Patrícia Melo. Espelhos partidos: etnia, legislação e desigualdade na colônia. Manaus: EDUA, 2012.

${ }^{9}$ Em uma perspectiva mais geral, para este debate sobre a política indigenista na Câmara e no Senado, veja de MACHADO, André Roberto de A. O Conselho Geral da Província do Pará e a definição da política indigenista no Império do Brasil (1829-31), op. cit., p. 181-237.

${ }^{10}$ Idem.

${ }^{11}$ Entre outros, veja de MACHADO, André Roberto de A. A quebra da mola real das sociedades, op. cit.
} 
O ECLIPSE do PRINCIPAL: APONTAMENTOS SOBRE AS MUdANÇAS DE HIERARQUias ENTRE OS INDÍGENAS DO Gráo-Pará e os impactos no CONTROLE da SUA Mão de obra (DÉCADAS DE I 820 E I 830 )

André Roberto de Arruda Machado

instituiçôes provinciais de regular o trabalho compulsório indígena, algo que culminará na criação do Corpo de Trabalhadores, em $1838 .{ }^{12}$

O desafio posto neste artigo é, portanto, perceber como essa sobreposição de normas legais se materializou na realidade do Pará, frente aos conflitos entre os grupos e um mundo em mudanças, tanto no interior das sociedades indígenas como nos impérios que as envolviam.

\section{O eclipse do Principal}

Como dito anteriormente, nas décadas de 1820 e 1830 no Pará, as mençôes aos Principais, ou a termos correlatos, são raríssimas. Da documentação corrente entre autoridades até aqui consultada, encontrou-se apenas uma menção, justamente a grupos mundurucus aparentemente não aldeados. ${ }^{13}$

Mesmo no texto de viajantes atentos como Spix e Martius, que gastaram grande parte de suas narrativas para descrever os indígenas do Grão-Pará no começo da década de 1820, a menção aos Principais é rara. Durante todo o tempo em que narram seus encontros com comunidades indígenas em Belém e nas vilas próximas, vários aspectos são levantados, como a exploração do trabalho desses indivíduos, seu emprego em várias atividades, assim como a perda das distinçôes étnicas dos grupos há muito tempo habitando com os brancos, questão que é obsessivamente mencionada por esses naturalistas. ${ }^{14}$ No entanto, não é mencionada a figura dos Principais em quase a totalidade das povoaçôes visitadas, muito menos citada sua participação na administração ou em açôes de resistência dos indígenas..$^{15} \mathrm{~A}$ exceção a essa regra se dá quando a viagem ultrapassa o ponto de Tefé, já no interior do Rio Negro, em povoados como Santo Antonio de Maripi e São João do Príncipe. Ali, Spix e Martius mencionam Principais de indígenas juri, coretu, jumana. A realidade nesta regiáo, no entanto, parece mais fluida, com grupos indígenas convivendo parte nas vilas e parte nos matos, além de alguns grupos tendo, aparentemente, um contato apenas circunstancial com os brancos, com grande independência. Além disso, a clara distinção étnica dos grupos, vinculando um líder a cada povo, contrasta com a realidade descrita em outras povoações. Contudo, não se pode negar a citação de Principais de grupos claramente aldeados, inclusive com a denúncia

\footnotetext{
${ }^{12}$ MACHADO, André Roberto de A. O Conselho Geral da Província do Pará e a definição da política indigenista no Império do Brasil (1829-31) , op. cit., p. 181-237.

${ }^{13}$ Arquivo Público do Pará, doravante APEP, códice 854, doc. 94, em 18 de junho de 1834.

${ }^{14}$ SPIX, Johann B. von; MARTIUS, Karl Friedrich P. von. Viagem pelo Brasil, 1817-1820. Trad. Lúcia Furquim Lahmeyer. Belo Horizonte: Editora Itatiaia; São Paulo: Editora da Universidade de São Paulo, 1981, v. 3.

${ }^{15}$ Por outro lado, em uma nota sobre os índios no Grão-Pará faz algumas consideraçóes bastante genéricas, entre as quais a de que os indígenas que estavam sob controle de um Principal passavam a constar na lista dos juízes e, entáo, eram considerados súditos brasileiros (sic). No entanto, a suposta onipresença dos Principais na organização desses indígenas não se reflete na descrição feita pelos naturalistas das localidades visitadas. SPIX, Johann B. von; MARTIUS, Karl Friedrich P. von. Viagem pelo Brasil, 1817-1820, op. cit., p. 47.
} 
O ECLIPSE do PRINCIPAL: APONTAMENTOS SOBRE AS MUdANÇAS DE HIERARQUias ENTRE OS INDÍGENAS DO Gráo-Pará e os impactos no CONTROLE da SUA Mão de obra (DÉCADAS DE I 820 E I 830 )

dos naturalistas de que esses povos sofriam com os abusos do juiz local no emprego do trabalho compulsório. No entanto, a menção a esses Principais não dá grande importância às suas funçôes para além da sua capacidade de enfrentamento com outros grupos indígenas. É por isso que esses Principais são convidados a acompanhar os naturalistas no encontro com outros grupos, de forma a evitar possíveis ataques. ${ }^{16}$

Entre os Principais que eram temidos nessa região estava Pachico, líder dos coretu. Spix e Martius o descrevem como um líder ardiloso, que mantinha seus comandados longe das povoaçôes, mas sabia muito bem se beneficiar do contato com os brancos. Apresentando-se ao primeiro contato como súdito e funcionário do Rei, Pachico era conhecido por fazer guerra contra outros indígenas e vendê-los como escravos para os brancos, aborrecendo-se com os comentários dos naturalistas, que o aconselharam a largar a venda de escravos e dedicar-se à produçáo agrícola. A posição dúbia, entre "avilado" e independente, que talvez fosse mais comum do que o contrário, não esconde que a fonte central de poder desse Principal estava claramente em confronto com a Carta Régia de 1798: a escravização dos ameríndios. Já ao falar dos Principais Miguel e João Manuel, respectivamente líderes dos juri e dos miranha, Spix e Martius os classificavam como indígenas que tinham contato com os brancos, mas eram "independentes" ou "do mato". Tal como Pachico, o poder desses Principais estava diretamente ligado à sua transação de mão de obra com os brancos: enquanto João Manuel oferecia escravos, Miguel trazia indígenas do interior e os "alugava" aos brancos mediante salários. ${ }^{17}$

Não bastassem as poucas e localizadas citaçóes aos Principais na narrativa de Spix e Martius, em vários momentos o apoio do seu poder aparece em mençóes e símbolos antigos. Em Santo Antonio do Maripi, ao citarem os Principais, por exemplo, dizem que são cargos que vêm do Diretório. É preciso lembrar, no entanto, que o chamado Diretório, já citado neste texto anteriormente, tratava-se da política estabelecida pelo marquês de Pombal para os indígenas na metade do século XVIII. E como mencionado na introdução deste texto, ao contrário da maior parte do Brasil, no Pará a Carta Régia de 1798 significou o fim da política do Diretório para os indígenas. Reafirma essa situaçáo anacrônica, fora do lugar, a surpreendente descrição do Principal Pachico: em tom irônico, os naturalistas lembram que ele aparece com uma casaca azul e empunhando uma cana com borda de prata, um símbolo de poder das lideranças indígenas concedidas ainda por Mendonça Furtado, durante o Diretório. ${ }^{18}$

As poucas mençóes aos Principais, nas décadas de 1820 e 1830, nos obrigam a refletir sobre as possíveis mudanças na organizaçôes das sociedades indígenas no Pará após a Carta Régia de 1798. Até aí, as organizaçóes em aldeamentos tinham nos Principais uma peça-chave. Quase visto como uma invenção do Diretório pelos autores costumeiramente dedicados ao tema, na verdade os Principais são um elemento central da organizaçáo dos aldeamentos em toda a colonização, como bem mostrou Almeida em casos emblemáticos

\footnotetext{
${ }^{16}$ Ibidem, p. 207-218.

${ }^{17}$ Ibidem, p. 219-230.

${ }^{18}$ Ibidem, p. 207-219. 
O ECLIPSE do PRINCIPAL: APONTAMENTOS SOBRE AS MUdANÇAS DE HIERARQUias ENTRE OS INDÍGENAS DO Gráo-Pará e os impactos no CONTROLE da SUA Mão de obra (DÉCADAS DE I 820 E I 830 )

como o de Arariboia. ${ }^{19}$ O Diretório apenas aprofundou a reelaboração dessa figura. Afinal, como mostram diversos autores, nos primeiros contatos os europeus ficavam admirados com a obediência dos tupi aos seus líderes, sobretudo porque não identificavam sistemas de coerção, hierarquias rígidas ou vantagens econômicas dos Principais sobre seus comandados. Ao mesmo tempo, se o amálgama dessas comunidades era prestígio do chefe, continuamente essa autoridade era posta em xeque, resultando em divisôes do grupo e na reafirmação da inexistência de hierarquias rígidas. ${ }^{20} \mathrm{Se}$ isso valia para os tupi, não há indícios que outros grupos tivessem cadeias de comando mais centralizadas na região do Grão-Pará. ${ }^{21}$

Como dito anteriormente, o Diretório Pombalino apenas aprofundou a reelaboração dessa figura que já existia nos antigos aldeamentos. Como a política indigenista proposta por Pombal através do Diretório tinha como seu objetivo último a transformaçáo dos indígenas em portugueses - fosse para garantir assim a posse sobre os territórios conquistados no Tratado de Madri, fosse para assegurar os braços necessários para a colonização além dos escravos africanos - os Principais foram vistos como um elo importante tanto na tentativa de transformação dos indígenas em súditos como para organizar a mão de obra desses indivíduos. Para isso, Portugal garantiu aos Principais poder e prestígio o suficiente para que vários autores tenham identificado esse processo como o da constituição de uma elite indígena. ${ }^{22}$

Dessa forma, apesar da manutenção do termo "Principais", essas lideranças indígenas nos aldeamentos coloniais exerciam um poder muito mais hierarquizado, garantido em grande parte pela sua relação com a colonização portuguesa, que ainda respeitava a sucessão do cargo a descendentes. ${ }^{23}$ No Diretório, um dos pilares desse poder estava na distribuição dos indígenas para os trabalhos externos, sobretudo a coleta de drogas do sertão. Ainda que o Diretor tivesse o maior poder de decisão sobre essa partilha, cabia ao Principal uma parcela dessas açôes, o que lhe garantia grande prestígio. ${ }^{24}$ Além da distribuição dos trabalhadores,

\footnotetext{
${ }^{19}$ ALMEIDA, Maria Regina Celestino de. Metamorfoses indígenas: identidade e cultura nas aldeias coloniais do Rio de Janeiro, op. cit.

${ }^{20}$ MONTEIRO, John Manuel. Os negros da terra: índios e bandeirantes nas origens de São Paulo. São Paulo: Companhia das Letras, 1994, p. 18-29; PERRONE-MOISÉS, Beatriz; SZTUTMAN, Renato. Notícias de uma certa confederação tamoio. Mana, v. 16, n. 2, p. 401-433, 2010, p. 401-433.

${ }^{21}$ FAUSTO, Carlos. Os índios antes do Brasil. 4. ed., Rio de Janeiro: Zahar, 2010.

${ }^{22}$ DOMINGUES, Ângela. Quando os indios eram vassalos: colonização e relações de poder no Norte do Brasil na segunda metade do século XVIII. Lisboa: Comissão Nacional para as comemoraçóes dos descobrimentos portugueses, 2000, p. 169-177; SAMPAIO, Patrícia Melo. Espelhos partidos: etnia, legislação e desigualdade na colônia. Manaus: EDUA, 2012, p. 193-207; ROCHA, Rafael Ale. Os oficiais indios na Amazônia pombalina: sociedade, hierarquia e resistência (1751-1798). Dissertação (Mestrado) — Niterói: UFF, 2009, p. 50-92. ${ }^{23}$ COELHO, Mauro Cezar. Do sertão para o mar: um estudo sobre a experiência portuguesa na América, a partir da colônia: o caso do Diretório dos Índios (1750-98). Tese (Doutorado) — São Paulo: USP, 2005, p. $208-221$.

${ }^{24}$ Mesmo antes do Diretório, o Principal tinha a função do recrutamento de mão de obra nos aldeamentos para serviços externos. ALMEIDA, Maria Regina Celestino de. Metamorfoses indígenas: identidade e cultura nas aldeias coloniais do Rio de Janeiro, op. cit., p. 195-198; SAMPAIO, Patrícia Melo. Espelhos partidos: etnia, legislação e desigualdade na colônia, op. cit., p. 149-162.
} 
O ECLIPSE do PRINCIPAL: APONTAMENTOS SOBRE AS MUdANÇAS DE HIERARQUias ENTRE OS INDÍGENAS DO

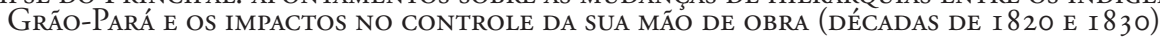

André Roberto de Arruda Machado

o Diretório reservava aos Principais, assim como a outros oficiais indígenas, o privilégio de mandarem indígenas coletarem drogas do sertão em seu benefício comercial, ainda que esses ficassem obrigados a pagar salários, como cabia a todos os contratantes. ${ }^{25}$ Ficava assim estabelecido um benefício econômico e social dos Principais sobre seus comandados, algo que Rafael Rocha demonstra que não só foi incorporado por essas lideranças, como ainda coube a alguns desses indivíduos o esforço de peticionar ao rei pelo aumento dessas vantagens. ${ }^{26}$ Além do papel na distribuição de trabalhadores indígenas, Patrícia Sampaio assinala que o prestígio dos Principais no Diretório também estava alicerçado na sua função estratégica dos novos descimentos - grosso modo, trazer indígenas que ainda estavam nas florestas mecanismo imprescindível para a manutenção e reprodução das populações nas novas vilas pombalinas. $^{27}$

É justamente em torno dos Principais que se tem reavaliado a atuação dos indígenas no Diretório, até então visto como uma política de aniquilamento das identidades ameríndias e de suas lideranças. ${ }^{28}$ Ainda que Nádia Farage tenha apontado limites para atuação dos Principais, chegando a chamá-los de "capatazes do diretor" ${ }^{29}$, hoje se sabe que a liderança desses indivíduos não se dava apenas na repartição dos trabalhadores, mas se concretizava também em movimentos de resistência que não significavam apenas a negativa ao sistema colonial, mas muitas vezes exigir condiçôes adequadas às suas expectativas. Nesse sentido, um dos aspectos mais notáveis da tese de Patrícia Sampaio foi demonstrar algumas dessas açôes de resistência lideradas pelos Principais durante o Diretório, o que lhe valeu defender a ideia de Barbara Sommer de uma "colonização negociada". ${ }^{30}$

Sem dúvida alguma, essa presença tão marcante dos Principais ajudava a manter contornos mais claros das comunidades indígenas, certamente algo que impactava em suas identidades. Se o sucesso da estratégia de valorização dos Principais tinha como efeito colateral um

${ }^{25}$ DIRETÓRIO que se deve observar nas povoações dos índios do Pará e Maranhão enquanto sua majestade não mandar o contrário. Lisboa, Oficinal de Miguel Rodrigues, 1758, artigos 9, 46 a 54, 62, 71; SAMPAIO, Patrícia Melo. Espelhos partidos: etnia, legislação e desigualdade na colônia, op. cit., p. 137-148.

${ }^{26}$ ROCHA, Rafael Ale. Os oficiais indios na Amazônia pombalina: sociedade, hierarquia e resistência (17511798), op. cit. p. 115-128; COELHO, Mauro Cezar. Do sertão para o mar: um estudo sobre a experiência portuguesa na América, a partir da colônia: o caso do Diretório dos Índios (1750-98), op. cit., p. 254.

${ }^{27}$ SAMPAIO, Patrícia Melo. Espelhos partidos: etnia, legislação e desigualdade na colônia, op. cit., p. 137-148; FARAGE, Nádia. As muralhas dos sertóes: os povos indígenas no Rio Branco e sua colonização. Rio de Janeiro: Paz e Terra, 1991, p. 34-55; ROCHA, Rafael Ale. Os oficiais índios na Amazônia pombalina: sociedade, hierarquia e resistência (1751-1798), op. cit., p. 18-50; ALMEIDA, Maria Regina Celestino de. Metamorfoses indigenas: identidade e cultura nas aldeias coloniais do Rio de Janeiro, op. cit., p. 92-101; DIRETÓRIO que se deve observar nas povoaçóes dos índios do Pará e Maranháo enquanto sua majestade não mandar o contrário, op. cit., artigos 78-79.

${ }^{28}$ MOREIRA NETO, Carlos de Araújo. Índios da Amazônia: de maioria a minoria (1750-1850). Petrópolis: Vozes, 1988, p. 24-30.

${ }^{29}$ FARAGE, Nádia. As muralhas dos sertôes: os povos indígenas no Rio Branco e sua colonização, op. cit., p. $34-55$

${ }^{30}$ SAMPAIO, Patrícia Melo. Espelhos partidos: etnia, legislação e desigualdade na colônia, op. cit., p. 207-224. 
O ECLIPSE do PRINCIPAL: APONTAMENTOS SOBRE AS MUdANÇAS DE HIERARQUias ENTRE OS INDÍGENAS DO

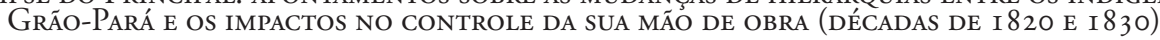

resultado contrário a uma política claramente assimilacionista de Pombal — que desejava transformar os indígenas tão somente em portugueses — somava-se a isso os limites da "integração" tão ambiciosamente proposta. Exemplo disso é a pretensão da coroa portuguesa de abolir no Estado do Grão-Pará e Maranhão a Língua Geral, revertendo um posicionamento de décadas que estimulara a sua disseminação em todos os níveis sociais. ${ }^{31}$ No entanto, como mostra José Ribamar Bessa Freire, a imposição do português como a língua materna na região teve efeitos parciais, com o nheengatu ainda tendo grande presença mesmo em Belém até meados do XIX. Mais do que isso, o domínio das línguas era um fator decisivo para a classificação dos indígenas em nomenclaturas como "tapuios", "índios civilizados" e "caboclos", algo que certamente tinha impacto na forma como a sociedade via esses indivíduos, mas também na construção das suas identidades. ${ }^{32}$

$\mathrm{Na}$ mesma linha dos limites da política pombalina está a transformação das antigas aldeias em vilas e povoados. De modo geral, essa é uma política tida como bem-sucedida pela bibliografia especializada, que ressalta a integração dos indígenas à sociedade colonial. ${ }^{33}$ No entanto, orientando o trabalho de Michelle Brito fomos surpreendidos pela organização das listas populacionais do final XVIII, nas quais procurávamos os desdobramentos do Diretório. No recenseamento de 1778 , há um número muito pequeno de famílias indígenas contabilizadas, exatamente 262 em toda a capitania, classificadas como "livres". Entre esses indígenas, na maioria classificados como lavradores, é possível encontrar desde chefes de família que possuíam dez escravos até aqueles que viviam de esmolas. ${ }^{34}$ Evidentemente, esse dado não poderia comportar o grande número de indígenas do Grão-Pará. Encontrou-se, então, mapas de população que incluíam um outro segmento: os índios aldeados, contados em mais de 29 mil habitantes.

Partindo da ideia de que as vilas anteriormente existentes tinham sido dissolvidas, dando origem a vilas e povoados, a pergunta que ficava era quem seriam os "índios aldeados" e por que eles não estavam contados no recenseamento como "livres"? Originalmente, especulou-se que os "aldeados" pudessem ser aqueles recentemente descidos, talvez em uma etapa transitória até as vilas, mas o número pequeno de "livres" não comportava os antigos indígenas reduzidos. Dessa forma, a constatação duplamente surpreendente é que os indígenas que viviam nas novas vilas podiam ser classificados como "aldeados" e um pequeno número como "livres". Sobre esses livres, chegou-se a cogitar que correspondessem aos Principais ou outros

${ }^{31}$ BELLOTO, Heloísa Liberalli. Política indigenista no Brasil Colonial (1570-1757). Revista do Instituto de Estudos Brasileiros, São Paulo, n. 29, 1988; FREIRE, José Ribamar Bessa. Rio Babel: a história das línguas na Amazônia. Rio de Janeiro: Eduerj, 2004.

${ }^{32}$ FREIRE, José Ribamar Bessa. Rio Babel: a história das línguas na Amazônia, op. cit., p. 179-185.

33 Ibidem, p. 179-185; DOMINGUES, Ângela. Quando os indios eram vassalos: colonização e relaçôes de poder no Norte do Brasil na segunda metade do século XVIII, op. cit., 76-89.

${ }^{34}$ BRITTO, Michelle Carolina de. O Diretório Pombalino e os índios no Grão-Pará setecentista (17501798). Monografia de fim de curso - Unifesp, Guarulhos, 2014, p. 73-74. 
O ECLIPSE do PRINCIPAL: APONTAMENTOS SOBRE AS MUdANÇAS DE HIERARQUias ENTRE OS INDÍGENAS DO Gráo-Pará e os impactos no CONTROLE da SUA Mão de obra (DÉCADAS DE I 820 E I 830 )

membros da dita "elite indígena", mas não há evidências nesse sentido. $\mathrm{O}$ máximo que se encontrou foi um indígena classificado como livre que era também Diretor de Santarém. ${ }^{35}$

Como pondera Sampaio, a própria criaçáo dessas classificaçóes no censo, sobretudo a de "índios aldeados" e "livres", mostra claramente os limites da integração proposta pela política pombalina. ${ }^{36}$ Além disso, a descrição dos mapas populacionais demonstra não só uma falta de integração de todos os indígenas na simples categoria de homens livres, mas também uma distinção geográfica. Os mapas usam bastante termos como "locais de branco" e "locais de índio", sendo clara a concentraçáo de cada grupo em espaços geográficos distintos. ${ }^{37}$ Evidentemente, os censos não reproduziam a realidade e uma das maiores demonstraçôes disso é o número muito pequeno de índios em Belém, quando todos os relatos de viajantes apontam para o contrário. As razóes para isso já foram demonstradas em outros estudos e vão desde a lógica pela qual eram feitos esses censos - com base em documentos da igreja e desta forma ignorando parte dos indígenas não frequentes aos ritos católicos — até o interesse em não revelar a existência desses homens em condições ilegais, como escravos, por exemplo. ${ }^{38}$

Também é verdade que houve o incentivo à convivência com os brancos no mesmo território e há notícias de resultados práticos dessa política, inclusive com o casamento de colonos e indígenas. Os mapas, no entanto, dão a entender que os resultados da integração foram limitados, devendo-se lembrar que a entrada de qualquer branco no território dos indígenas dependia do acordo do Diretor. Da mesma forma, contornos geográficos tâo explícitos e aparentemente tão rígidos dos chamados "lugares de índios" deviam estar ligados à capacidade do Diretor de controlar o trânsito dos indígenas. Apesar de serem considerados homens livres, o deslocamento dos "aldeados" era controlado e os que deixavam o lugar de residência ou se demoravam mais do que o esperado em trabalhos externos, eram considerados como "desertores" e podiam ser procurados pelo Diretor que deveria trazê-los de volta. ${ }^{39}$ Este aspecto só pode ser entendido para além do que está na superfície da sempre alegada necessidade de manter as vilas povoadas: era um mecanismo importante para garantir o volume de trabalhadores indígenas disponíveis. Nesse sentido, se Alencastro tem razão na importância do esforço de Pombal em irrigar o Estado do Grão-Pará e Maranhão com o

\footnotetext{
${ }^{35}$ Ibidem, p. 75-76.

${ }^{36}$ SAMPAIO, Patrícia Melo. Espelhos partidos: etnia, legislação e desigualdade na colônia, op. cit., p. 76-77.

${ }^{37}$ BRITTO, Michelle Carolina de. O Diretório Pombalino e os índios no Grão-Pará setecentista (17501798), op. cit.; COELHO, Mauro Cezar. Do sertão para o mar: um estudo sobre a experiência portuguesa na América, a partir da colônia: o caso do Diretório dos Índios (1750-98), op. cit., p. 203.

${ }^{38}$ MACHADO, André Roberto de A. A quebra da mola real das sociedades: a crise política do Antigo Regime Português na província do Grão-Pará (1821-25), op. cit., p. 63-64; FREIRE, José Ribamar Bessa. Rio Babel: a história das línguas na Amazônia, op. cit.; BRITTO, Michelle Carolina de. O Diretório Pombalino e os índios no Grão-Pará setecentista (1750-1798), op. cit.

${ }^{39}$ DIRETÓRIO que se deve observar nas povoaçôes dos índios do Pará e Maranhão enquanto sua majestade não mandar o contrário, op. cit., artigos 73 a 76.
} 
O ECLIPSE do PRINCIPAL: APONTAMENTOS SOBRE AS MUdANÇAS DE HIERARQUias ENTRE OS INDÍGENAS DO Gráo-Pará e os impactos no CONTROLE da SUA Mão de obra (DÉCADAS DE I 820 E I 830 )

tráfico negreiro, por sua vez o Diretório não pode ser visto apenas como uma lei de garantia de liberdade. Ao contrário, era uma das formas de assegurar a mão de obra indígena. ${ }^{40}$

A força explícita das lideranças, assim como os contornos claros das comunidades se aproximam do cenário descrito por Almeida também para o Rio de Janeiro, elementos fundamentais para que ela pensasse a identidade de indígena aldeado. ${ }^{41}$ No entanto, Almeida náo menciona alteraçóes nesse cenário no Rio de Janeiro, a partir da Carta Régia de 1798, o que corrobora a afirmação de Sampaio, mencionada anteriormente, de que a aplicaçáo dessa lei se restringiu ao Grão-Pará. ${ }^{42}$ No entanto, no Grão-Pará essas mudanças existiram e parecem ter atingido a organização social até aqui descrita. A lei de 1798 não acabou apenas com a tutela dos Diretores sobre os indígenas, mas também promoveu uma série de mudanças na organização de dois pontos sensíveis para o mundo dos "índios avilados": a organização da sua mão de obra e das vilas da província. ${ }^{43}$

Sobre esse último ponto, Moreira Neto insiste que um dos pontos mais sensíveis da lei de 1798 foi a venda dos bens coletivos das antigas aldeias e a aceleração da entrada de colonos nas terras antes ocupadas pelos indígenas. ${ }^{44}$ Como um resultado possível dessas mudanças, na famosa descrição estatística de Monteiro Ladislau Baena, em seu Ensaio corográfico, a situação na década de 1830 não apresenta separaçóes territoriais tão estanques entre esses grupos. Não há mais uma descrição de "lugares de índios" e "lugares de brancos". São raras as vilas compostas exclusivamente por índios e mamelucos, e quando isso ocorre estáo localizadas especialmente no Rio Negro e em alguns poucos lugares classificados como "missóes". Ainda que existissem alguns lugares com enorme concentração ou de indígenas, ou de brancos, o que mais chama a atenção é a progressiva mistura desses dois grupos, quando comparado ao quadro do Diretório. ${ }^{45}$ Baena chega mesmo a descrever mais detalhadamente algumas situaçôes, como o crescimento da população de brancos que compravam e se instalavam em terras dos indígenas da antiga aldeia de Santarém. ${ }^{46} \mathrm{Na}$ detalhada descrição dos

${ }^{40}$ ALENCASTRO, Luiz Felipe de. O trato dos viventes. Formação do Brasil no Atlântico Sul. São Paulo: Companhia das Letras, 2000, p. 142-143; SAMPAIO, Patrícia Melo. Espelhos partidos: etnia, legislação e desigualdade na colônia, op. cit.; COELHO, Mauro Cezar. Do sertão para o mar: um estudo sobre a experiência portuguesa na América, a partir da colônia: o caso do Diretório dos Índios (1750-98), op. cit., p. 25. ${ }^{41}$ ALMEIDA, Maria Regina Celestino de. Metamorfoses indígenas: identidade e cultura nas aldeias coloniais do Rio de Janeiro, op. cit.

${ }^{42}$ SAMPAIO, Patrícia Melo. Espelhos partidos: etnia, legislação e desigualdade na colônia, op. cit..

${ }^{43}$ CARTA RÉGIA DE 1798 (e esclarecimentos sobre a sua aplicação). In: MOREIRA NETO, Carlos de Araújo. Índios da Amazônia: de maioria a minoria (1750-1850). Petrópolis: Vozes, 1988.

${ }^{44}$ MOREIRA NETO, Carlos de Araújo. Índios da Amazônia: de maioria a minoria (1750-1850), op. cit., p. 30-31; SAMPAIO, Patrícia Melo. Espelhos partidos: etnia, legislação e desigualdade na colônia, op. cit., p. 225-244.

${ }^{45}$ BAENA, Antonio Ladislau Monteiro. Ensaio corográfico sobre a provincia do Grão-Pará. Pará: Typographia de Santos \& Menor, 1839.

${ }^{46}$ Ibidem, p. 334. Passando por Santarém na segunda metade da década de 1820, Hercules Florence fez uma descrição que dá a entender a manutenção de uma separação geográfica perceptível entre indígenas e brancos, dizendo que Santarém, assim como outros povoados, tinha sua ““aldeia de índios”“. Evidentemente, isto 
O ECLIPSE do PRINCIPAL: APONTAMENTOS SOBRE AS MUdANÇAS DE HIERARQUias ENTRE OS INDÍGENAS DO

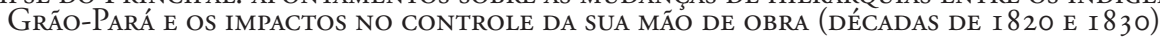

André Roberto de Arruda Machado

povoados, também é interessante sublinhar que Baena cita várias vezes antigos Principais, na maior parte das vezes indicados como responsáveis pelos descimentos originais, mas náo cita um único Principal contemporâneo ao período em que está escrevendo, a década de $1830 .{ }^{47}$

Um fator da maior distribuição desses grupos certamente está na eliminação de qualquer controle no trânsito dos indígenas a partir da lei de 1798. Esta foi uma mudança contra a qual resistiram os agentes coloniais, muitas vezes acusando indígenas de deserção por simplesmente deixarem as aldeias. ${ }^{48} \mathrm{Da}$ mesma forma, vale ressaltar que esse foi um dos aspectos mais contestados pelos críticos da lei de 1798 nas décadas de 1820 e 1830, sendo frequentemente apontado como a razão do esvaziamento das vilas. ${ }^{49}$ Baena, um dos mais ferozes críticos dessa lei, sublinha a espantosa perda populacional entre o final do século XVIII e 1833 , com vilas que deixaram de ter centenas de casas para se restringir a algumas poucas. ${ }^{50}$

Voltando à questáo dos Principais, a lei de 1798 alterou outra fonte do seu poder: os descimentos - grosso modo, expediçóes que tinham como objetivo trazer indígenas que habitavam as florestas para as vilas e aldeias - atividade na qual essas lideranças eram protagonistas. O texto da lei de 1798 é bastante incisivo ao proibir os descimentos, deixando claro que não poderia se contar com apoio do governo para isso. ${ }^{51}$ Patrícia Sampaio, corretamente, assinala que a mesma lei deixava uma brecha ao permitir que particulares não efetuassem o descimento, mas que pudessem abrigar indígenas que, supostamente, tivessem voluntariamente desejado se instalar nas suas propriedades. A esses particulares era garantido, com a regulação das câmaras, o direito de contar com o trabalho desses indivíduos por alguns anos, como forma de indenização por seus gastos na civilização desses homens. ${ }^{52}$ Sem dú-

expressa a visão do viajante, não quer dizer que seja uma informação precisa. Veja FLORENCE, Hércules. Viagem fluvial do Tietê ao Amazonas de 1825 a 1829. Brasília: Senado Federal, 2007, p. 263.

${ }^{47}$ BAENA, Antonio Ladislau Monteiro. Ensaio corográfico sobre a província do Grão-Pará, op. cit. Da mesma forma, parece significativo que em seu plano para civilização dos indígenas Baena não tenha citado a existência dos principais e tampouco tenha pensado em uma função para esses homens no novo governo que projetava. BAENA, Antonio Ladislau Monteiro. Representação ao Conselho Geral da Província do Pará sobre a especial necessidade de um novo regulamento promotor da civilização dos índios da mesma província. In: Arquivo Público do Estado do Pará (APEP). Anais da Biblioteca e Arquivo Público do Pará. Tomo 2, Belém: Imprensa Oficial, 1902.

48 SAMPAIO, Patrícia Maria Melo. "Vossa Excelência mandará o que for servido”...: políticas indígenas e indigenistas na Amazônia Portuguesa do final do século XVIII. Tempo, n. 23, p. 39-55, 2007.

${ }^{49}$ MACHADO, André Roberto de A. O fiel da balança: o papel do parlamento brasileiro nos desdobramentos do golpe de 1831 no Grão-Pará. Revista de História (USP), São Paulo, n. 164, 2011. Exemplos dessas críticas à Carta Régia de 1798, especialmente a falta de controle do trânsito dos indígenas, podem ser encontrados nas propostas de civilização para os índios escritas por Ladislau Monteiro Baena e por José Ricardo Zany. Veja BAENA, Antonio Ladislau Monteiro. Representação ao Conselho Geral da Província do Pará sobre a especial necessidade de um novo regulamento promotor da civilização dos índios da mesma província, op. cit.; ZANY, José Ricardo. Projeto para os índios do Grão-Pará. In: Diário das Cortes, 1821/1822. Sessão de 26 de agosto de 1822. Disponível em: <http://debates.parlamento.pt>.

${ }^{50}$ BAENA, Antonio Ladislau Monteiro. Ensaio corográfico sobre a província do Grão-Pará, op. cit.

${ }^{51}$ CARTA RÉGIA DE 1798 (e esclarecimentos sobre a sua aplicação), op. cit., p. 441.

52 SAMPAIO, Patrícia Melo. Espelhos partidos: etnia, legislação e desigualdade na colônia, op. cit., p. 233. 
O ECLIPSE do PRINCIPAL: APONTAMENTOS SOBRE AS MUdANÇAS DE HIERARQUias ENTRE OS INDÍGENAS DO Gráo-Pará e os impactos no CONTROLE da SUA Mão de obra (DÉCADAS DE I 820 E I 830 )

André Roberto de Arruda Machado

vida alguma, alguns dos maiores desafios para dimensionar o tamanho da mão de obra dos indígenas no Grão-Pará do século XIX estão nesses "educandos", assim como dos escravos, obtidos ilegalmente ou supostamente amparados pela lei de Guerra Justa de $1808 .{ }^{53}$ Apesar dessa brecha, é necessário não esquecer que um dos pontos mais incisivos dos críticos da lei de 1798 era justamente as restrições aos descimentos. ${ }^{54}$ Além disso, deve-se considerar que o "descimento" para propriedades particulares, a princípio, não permitia as mesmas prerrogativas de governo aos Principais que estavam dadas nas vilas. ${ }^{55}$

No entanto, a maior mudança da lei de 1798 para os Principais foi em relação à organização do trabalho dos indígenas. Baseado no argumento da inclinação natural dos indígenas à ociosidade, a lei de 1798 acabou com a tutela dos Diretores, mas manteve mecanismos para obrigar os "índios avilados" ao trabalho. A partir de entâo, todos os indígenas que habitavam as vilas, povoados e a cidade deviam ser alistados na Milícia de Ligeiros, sujeitos ao oficial desse corpo. Todos os homens dessa lista que não possuíssem ofícios ou estabelecimentos próprios com um certo rendimento estavam obrigados a servir por um período em obras públicas ou para particulares. ${ }^{56}$ Como aponta Patrícia Sampaio, a Carta Régia representou uma perda de poder e prestígio para os Principais, retirando deles a repartição da mão de obra dos indígenas avilados e passando a concentrar essas atividades na câmara e, especialmente, nos juízes, além da execução propriamente dita feita pelos oficiais da Milícia de Ligeiros. ${ }^{57}$

\footnotetext{
${ }^{53}$ Como amplamente discutido na historiografia, um dos fatos marcantes logo depois da chegada de d. João à América foi a decretação de guerra justa aos indígenas. As Guerras Justas eram artifício utilizado na Europa contra os mulçumanos, uma guerra supostamente justificada por se praticar contra os infiéis. Como apontado por outros autores, aplicada à América essa ideia era incoerente. Mesmo assim serviu para provocar o extermínio de muitas sociedades indígenas ao longo da colonização. Além de "limpar" o território, as guerras justas tinham outro objetivo: os homens presos nessas guerras podiam ser escravizados, destino de muitos indígenas. A Guerra Justa decretada por d. João foi lida por alguns autores como uma mudança radical em relação às políticas anteriores para os indígenas, sobretudo a pombalina, muito mais direcionada para incorporação dessas sociedades.
}

O fato é que no Pará a Guerra Justa decretada por d. João contra povos específicos, das regiōes Sudeste e Sul, foi deturpada para produzir escravos indígenas. Certamente, este foi apenas um dos artifícios para essa prática que, como era ilegal, é difícil de dimensionar. No entanto, para se ter uma ideia de como era disseminada, Spix e Martius chegam a dizer que era comum encontrar no Pará senzalas destinadas a escravos indígenas.

${ }^{54}$ MACHADO, André Roberto de A. O fiel da balança: o papel do parlamento brasileiro nos desdobramentos do golpe de 1831 no Grão-Pará, op. cit.

${ }^{55}$ Como tudo na política indigenista, há um labirinto de exceçôes. Nesse sentido, Baena menciona que Vila Nova da Rainha começou como uma missão organizada a partir dos descimentos de índios no começo do XIX. BAENA, Antonio Ladislau Monteiro. Ensaio corográfico sobre a provincia do Grão-Pará, op. cit., p. $452-453$.

${ }^{56}$ MACHADO, André Roberto de A. A quebra da mola real das sociedades: a crise política do Antigo Regime Português na província do Grão-Pará (1821-25), op. cit., p. 62-89; SAMPAIO, Patrícia Melo. Espelhos partidos: etnia, legislação e desigualdade na colônia, op. cit., p. 230-238; MOREIRA NETO, Carlos Araújo. Índios da Amazônia: de maioria a minoria (1750-1850), op. cit., p. 30-31.

${ }^{57}$ SAMPAIO, Patrícia Melo. Espelhos partidos: etnia, legislaçáo e desigualdade na colônia, op. cit., p. 232244; SAMPAIO, Patrícia Maria Melo. "Vossa Excelência mandará o que for servido...” “...: políticas indígenas e indigenistas na Amazônia Portuguesa do final do século XVIII", op. cit. 
O ECLIPSE do PRINCIPAL: APONTAMENTOS SOBRE AS MUdANÇAS DE HIERARQUias ENTRE OS INDÍGENAS DO Gráo-Pará e os impactos no CONTROLE da SUA Mão de obra (DÉCADAS DE I 820 E I 830 )

Como explica Sampaio, assim como no Diretório, os indígenas e os Principais poderiam concorrer e ocupar esses cargos. Aliás, vários trabalhos demonstram que no século XIX os indígenas ocupavam cargos de juízes, vereadores, além de vários postos na hierarquia das forças armadas. ${ }^{58}$ Também é possível verificar revoltas lideradas por indígenas no século XIX que estavam ligadas à eleição de postos para a Câmara e, de modo direto, ao recrutamento de mão de obra.

Um exemplo disso ocorreu no final de 1823, quando a população de Cintra — destacadamente os indígenas - fizera uma grande revolta. Ao comentar seus esforços para dissuadir os indígenas à paz, André Fernandez de Souza escreveu uma carta muito reveladora. Souza informava que esses habitantes exigiam direitos baseados no princípio de que aquela era a terra dos seus antepassados, o que Souza negou, dizendo que estavam ali por terem sido trazidos pelos jesuítas. Ainda mais interessante é que os revoltosos listaram por escrito as razóes do seu levante: tudo girava em torno do tenente Domingos Teixeira, que segundo eles tinha sido diretor, depois juiz (e, consequentemente, presidente da Câmara) e até aquela data controlava com mãos de ferro as eleiçôes, de forma que esse posto fosse seu domínio absoluto. Contra isso os revoltosos se queixavam, demonstrando que as consequências eram humilhaçóes e castigos contra os indígenas, além da exploração do seu trabalho para fins desse "partido". 59

Apesar do esforço dos indígenas em ocupar os espaços nas Câmaras, a documentação náo a tem mostrado como um elemento central no recrutamento nas décadas de $1820 \mathrm{e}$ 1830, com exceção do papel do juiz que é marcante no começo da década de 1820 e, como se verá, vai perdendo espaço para o oficial de Milícias de Ligeiros. No último tópico deste artigo, no entanto, buscaremos demonstrar que as câmaras, apesar do seu papel cada vez mais limitado, buscavam participar das disputas em torno da mão de obra dos indígenas, tanto para requisitá-la como para exigir respeito a isençôes e procedimentos legais.

Além dos postos nas câmaras, os Principais também podiam ocupar a posição de oficiais de Milícias de Ligeiros. Ao descrever a estrutura de recrutamento dos indígenas no Espírito Santo, Vânia Moreira aposta que eram os antigos Principais que ocupavam os cargos de oficiais de ordenança. ${ }^{60}$ No entanto, a verdade é que Moreira não aponta documentos que comprovem essa hipótese. Em linha próxima, Sampaio também acredita que os postos de

\footnotetext{
${ }^{58}$ MACHADO, André Roberto de A. A quebra da mola real das sociedades: a crise política do Antigo Regime Português na província do Grão-Pará (1821-25), op. cit.; CLEARY, David. Lost Altogether to the Civilised World: Race and Cabanagem in Northern Brazil, 1750 to 1850. Comparative Studies in Society and History, v. 40, n.1, p. 109-135, 1998; NOGUEIRA, Shirley Maria Silva. Razóes para desertar: institucionalização do exército no Estado do Grão-Pará no último quartel do século XXVIII. Dissertação (Mestrado) — NAEA/ UFPA, Belém, 2000.

${ }^{59}$ APEP, códice 713, doc. 67 (12/12/1823) e 68.

${ }^{60}$ MOREIRA, Vânia Maria Losada. A serviço do império e da nação: trabalho indígena e fronteiras étnicas no Espírito Santo (1822-60), op. cit. Em sua leitura sobre a Carta Régia de 1798, Vânia Moreira enquadra a milícia para a qual eram recrutados os trabalhadores como uma ordenança. Isso será discutido posteriormente.
} 
O ECLIPSE do PRINCIPAL: APONTAMENTOS SOBRE AS MUdANÇAS DE HIERARQUias ENTRE OS INDÍGENAS DO Gráo-Pará e os impactos no CONTROLE da SUA Mão de obra (DÉCADAS DE I 820 E I 830 )

oficiais das Milícias de Ligeiros foram ocupados, em grande parte, pelos antigos Principais. No entanto, da mesma forma não existem indícios seguros disso e a lei náo obrigava a reserva de postos a esses sujeitos. No começo do XIX, Sampaio descreve a intercessão do governador do Rio Negro para que as patentes de oficiais Milícias de Ligeiros fossem confirmadas aos Principais, alegando que a lei de 1798 tinha tirado suas prerrogativas. Sampaio trabalha isso como uma comprovação de que esses postos foram ocupados por esses indígenas, mas a própria descrição dos caminhos dessa petição demonstra que apenas um terço dos suplicantes era de indígenas e, certamente, nem todos Principais. ${ }^{61}$ Além disso, como se verá adiante, o posicionamento político dos oficiais de Milícias de Ligeiros nas décadas de 1820 e 1830 também não favorece a sua ligação com os antigos líderes indígenas.

A liderança dos antigos Principais pode ter sido incorporada nas décadas de 1820 e 1830 em cargos das vilas e das milícias? Vamos explorar essas questōes nas páginas seguintes. No entanto, como adverte Sampaio, essa não é uma mudança pequena, pois o seu poder viria de um cargo eletivo que nada garantia que seria seu. $\mathrm{O}$ quase desaparecimento do termo "Principal" para os índios avilados sugere que essa liderança, tal como conhecida no século XVIII, não era mais um elo importante com o Estado. Resta saber como isso se manteve ou foi rearticulado entre os indígenas.

A perda da referência de lideranças fortes entre os indígenas e de definiçóes mais nítidas da geografia de suas comunidades sugere desafios para se pensar as suas identidades. Certamente, o modelo de Almeida para os índios aldeados no Rio de Janeiro no século XIX encontra aqui muitas diferenças, uma comunidade que parece muito mais frágil. No entanto, também parece um exagero a afirmaçáo de Sampaio que a lei de 1798 abria um espaço para uma "individualização" dos índios. Em uma linha semelhante, Mark Harris sugere que no século XIX as identidades eram muito fluidas, chegando a afirmar que um índio que possuísse bens podia ser considerado como um branco. ${ }^{62}$ No entanto, essa fluidez tinha um limite: a obrigação do trabalho compulsório pelos indígenas "avilados". Tal como sugeriu Vania Moreira para o Espírito Santo, a obrigação para o trabalho recolocava a condição de indígenas para esses homens, a despeito de toda a política ou discurso assimilacionista. ${ }^{63} \mathrm{~A}$ identificação desses homens como indígenas é muito clara por parte dos agentes do Estado. Da mesma forma, essa condição comum parece em alguns momentos ter fortalecido a percepção de alguma unidade ou a reivindicação da condição de "tapuio", como tentei indicar em outros estudos para o período da independência. ${ }^{64}$

\footnotetext{
${ }^{61}$ SAMPAIO, Patrícia de Melo. Espelhos partidos: etnia, legislação e desigualdade na colônia, op. cit., p. 264 e 294. ${ }^{62}$ HARRIS, Mark. Rebellion on the Amazon: the Cabanagem, Race, and popular culture in the North of Brazil, 1798-1840. Nova York: Cambridge University Press, 2010, p. 40-49. No extremo, Harris considera que um dos resultados mais expressivos da lei de 1798 foi tornar os índios avilados uma massa camponesa, compartilhando muito da cultura ribeirinha também vivida por brancos e negros dessas regiôes.

${ }^{63}$ MOREIRA, Vânia Maria Losada. A serviço do império e da nação: trabalho indígena e fronteiras étnicas no Espírito Santo (1822-60), op. cit, p. 35.

${ }^{64}$ MACHADO, André Roberto de A. A quebra da mola real das sociedades: a crise política do Antigo Regime Português na província do Grão-Pará (1821-25), op. cit.
} 
O ECLIPSE do PRINCIPAL: APONTAMENTOS SOBRE AS MUdANÇAS DE HIERARQUias ENTRE OS INDÍGENAS DO

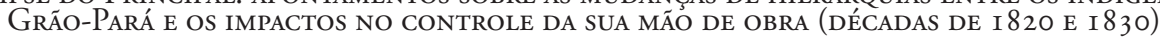

De toda forma, as mudanças provocadas pela Carta Régia de 1798 retiraram cada vez mais o controle das comunidades indígenas sobre a repartiçáo do seu trabalho, como visto um fator importante nas suas identidades. O fortalecimento do poder dos oficiais das Milícias de Ligeiros é um símbolo da perda de controle da comunidade sobre essa questão.

\section{O fortalecimento dos oficiais de Milícias de Ligeiros}

Como mencionado anteriormente, a partir da Carta Régia de 1798 uma das principais estruturas de recrutamento para o trabalho dos indígenas avilados era a Milícia de Ligeiros, na qual todos deveriam estar alistados e que teriam sobre seu comando oficiais próprios. Uma das questóes mais frequentes nas décadas de 1820 e 1830 foi a disputa pelo controle desses braços entre as autoridades civis e militares, o que por si só demonstra a importância que tinham esses corpos.

Patrícia Sampaio afirma que a lei garantia o controle desse corpo aos civis e apenas eventualmente aos militares. Para ela, parte do conflito estava na confusão ao ligar as Milícias de Ligeiros aos corpos de ordenança, algo que tinha sido extinto na mesma época. ${ }^{65} \mathrm{Na}$ verdade, o debate se essas milícias eram corpos militares propriamente ou de ordenanças não parece ser fruto apenas de um equívoco. Os grupos políticos mobilizavam argumentos contra ou a favor dessa tese conforme seus interesses. O já citado Baena, um militar português radicado em Belém, ao descrever a formação dos corpos de Ligeiros em sua corografia é enfático: ao ser criada essa milícia, foram desfeitas as antigas ordenanças, incluindo seus antigos membros no novo corpo militar. ${ }^{66} \mathrm{Já}$ em 1828, o barão de Bagé, então presidente da província, escrevia ao ministério defendendo que os Ligeiros eram ordenanças e que, portanto, deviam estar sob o controle dos civis e não dos militares. ${ }^{67}$ Foi com base no mesmo argumento, de que os Ligeiros eram ordenanças, que o cônego Batista Campos propôs uma representação no Conselho Geral de Província, em 1830, que foi enviada ao parlamento. Nesta representação, o conselho pedia que o parlamento interpretasse a lei de 1798 e confirmasse que as Milícias de Ligeiros eram ordenanças e que, portanto, deveriam estar sob poder dos civis. Em um lance surpreendente, no entanto, o parlamento decidiu extinguir o corpo de Ligeiros, ação que aguarda maior pesquisa para saber o alcance de sua real aplicação. ${ }^{68}$

É famosa a disputa entre militares e civis pelo controle da Milícia de Ligeiros durante o exercício do Governo das Armas pelo brigadeiro José Maria de Moura, entre abril de

\footnotetext{
${ }^{65}$ SAMPAIO, Patrícia de Melo. Espelhos partidos: etnia, legislação e desigualdade na colônia, op. cit., p. 236 e 291-292

${ }^{66}$ BAENA, Antonio Ladislau Monteiro. Ensaio corográfico sobre a província do Grão-Pará, op. cit., p. 163-164.

${ }^{67}$ APEP, Códice 869, doc. 3, 20 de maio de 1828.

${ }^{68}$ MACHADO, André Roberto de A. O fiel da balança: o papel do parlamento brasileiro nos desdobramentos do golpe de 1831 no Grão-Pará, op. cit.
} 
O ECLIPSE do PRINCIPAL: APONTAMENTOS SOBRE AS MUdANÇAS DE HIERARQUias ENTRE OS INDÍGENAS DO

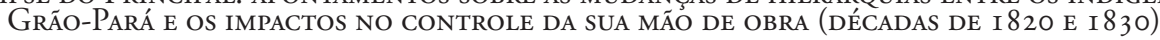

1822 e agosto de 1823. O Governador de Armas parece rapidamente ter compreendido a importância da máo de obra dos indígenas para o controle da província e buscou trazer para si o comando, o que gerou um conflito com a Junta de Governo Civil. ${ }^{69}$ Três meses após a sua chegada, já escrevia a Lisboa que não cumpriria uma lei de licenciamento das Milícias, dizendo que isso inviabilizaria o recrutamento dos indígenas para os diversos trabalhos na província. ${ }^{70}$ Há uma escalada na disputa entre civis e militares, com Moura passando Ligeiros até para serviços armados, enquanto o debate entre os poderes se materializava em cartas a Lisboa e até em textos no jornal $O$ Paraense. ${ }^{71}$

Patrícia Sampaio vê as açôes de Maria de Moura no comando das Armas como um momento em que o espaço dos militares no controle dos Ligeiros se amplia, inclusive com restriçôes aos papéis da câmara e dos juízes. ${ }^{72} \mathrm{O}$ barão de Bagé, na carta já citada, também aponta o governo de Moura como um período de mudança no controle dos Ligeiros. Para ele é a própria divisão entre poder civil e militar, desde o Vintismo, que cria essa questão e disputa. ${ }^{73}$ Longe de se restringir ao seu tempo no poder, parece que as açóes de Moura nessa questâo tiveram desdobramentos de longo alcance. Nesse sentido, os oficiais de Milícias de Ligeiros estão entre aqueles que sustentaram a permanência de Maria Moura no Pará, a despeito das ordens contrárias de Lisboa, ainda quando a província estava sob a órbita de Portugal. ${ }^{74}$ Essa foi a primeira de uma sequência de atos políticos nas décadas de 1820 e 1830 que teve esses oficiais como protagonistas. Logo depois, um golpe em março de 1823 depôs a Junta Civil que se opunha a Moura. A nova junta, entâo, expede um comunicado aos juízes ordinários, desautorizando um edital da junta anterior. Nessa nova instruçáo, deixava claro que os Ligeiros deveriam ficar sob o controle dos oficiais e não dos juízes, cabendo a esses últimos apenas solicitar aos comandantes os trabalhadores que fossem necessários. ${ }^{75}$

É possível que isso explique por que no começo da década de 1820 os juízes, como membros da Câmara, aparecem nas atividades de recrutamento e logo depois não aparecem mais na documentação nessa função. Os ofícios referentes ao recrutamento cada vez mais ampliam o papel dos oficiais das milícias. As açôes descritas parecem cada vez mais caçadas a esses trabalhadores, gerando pânico na população e enfrentamentos. Exemplo disso ocorreu em abril de 1827, quando uma máe indígena se desesperou ao ver a chegada de um

\footnotetext{
${ }^{69}$ Após a adesáo do Pará às Cortes de Lisboa, o governo da província, a exemplo de todo o império, passou a ser dividido entre uma Junta de Governo, civil e eleita localmente, e um Governo Militar, escolhido pelas Cortes.

${ }^{70}$ Arquivo Histórico Ultramarino (AHU), cx. 155, doc. 11.874 (Projeto Resgate). Em 6 de julho de 1822.

${ }^{71}$ MACHADO, André Roberto de A. A quebra da mola real das sociedades: a crise política do Antigo Regime Português na província do Grão-Pará (1821-25), op. cit, p. 157; SAMPAIO, Patrícia de Melo. Espelhos partidos: etnia, legislação e desigualdade na colônia, op. cit., p. 291-292; COELHO, Geraldo Mártires. Anarquistas, demagogos e dissidentes: a imprensa liberal no Pará de 1822. Belém: CEJUP, 1993, p. 255-256.

${ }^{72}$ SAMPAIO, Patrícia de Melo. Espelhos partidos: etnia, legislação e desigualdade na colônia, op. cit., p. 291-292.

${ }^{73}$ APEP, Códice 869, doc. 3, 20 de maio de 1828.

${ }^{74}$ APEP, Códice 742, doc. 66, 14 de fevereiro de 1823.

75 APEP, Códice 754, doc. 27, 6 de março de 1823.
} 
O ECLIPSE do PRINCIPAL: APONTAMENTOS SOBRE AS MUdANÇAS DE HIERARQUias ENTRE OS INDÍGENAS DO Gráo-Pará e os impactos no CONTROLE da SUA Mão de obra (DÉCADAS DE I 820 E I 830 )

oficial de Ligeiros e, acreditando que o filho seria recrutado, se dispôs a mostrar onde estavam escondidos militares que tinham participado de um levante em troca da liberdade do filho. ${ }^{76}$ Também em 1827, um oficial de milícias abriu um processo contra o padre Salvador Rodrigues, por ter destratado uma diligência que tinha ido à sua casa no meio da noite para conferir a denúncia de que o padre escondia Ligeiros do recrutamento. ${ }^{77}$ Mais do que isso, nos documentos também é possível enxergar algumas disputas entre juízes e os oficiais de ligeiros pelo controle desses braços, sempre com vantagem para os oficiais que parecem ter seu poder cada vez mais ampliado.

Exemplo disso está registrado em um ato de justificação, no começo de 1827, que tinha como objetivo coletar depoimentos contra ações do juiz ordinário de Pombal, Bernardino Antonio dos Reis. O requerente desse ato de justificação que denunciava as açôes do juiz era o capitão do corpo de milicianos ligeiros da vila de Gurupá, Antonio Rabello Mendes. Todo o processo e testemunhos contra o juiz gravitavam em torno da disputa pelo trabalho dos índios ligeiros. O capitão alegava e as testemunhas corroboraram que o juiz tinha por hábito maltratar os ligeiros os espancando, prendendo em troncos ou prisóes, o que na narrativa do capitão era a razão para a fuga dos indígenas das suas vilas. No entanto, a contenda com o juiz parece ser explicada menos pela preocupação com o bem-estar desses índios e muito mais pela disputa por essa mão de obra. Afinal, o capitão acusava Bernardino Reis de retirar os ligeiros que estavam destinados a servir no que ele chamava de "trabalhos de sua majestade" para serem empregados em suas atividades particulares. Fazia isso, segundo Antonio Mendes, através de todo o tipo de constrangimento sobre os índios, dizendo que era ele e não os oficiais de Ligeiros o verdadeiro governo sobre esses homens e imprimindo represálias contra os tapuios que se negassem a trabalhar em seus empreendimentos. Sua ação para garantir essa mão de obra tinha mesmo contornos surpreendentes. Segundo o capitão, era comum que o juiz escondesse os indígenas em sua casa nos momentos em que as diligências de ligeiros passavam para não serem identificados. Na narrativa do processo, ainda mais ousado teria sido sua ação de prender em plena atividade o sargento José Caetano, o que segundo os acusadores teria o objetivo de evitar o prosseguimento de uma diligência de recrutamento de ligeiros. ${ }^{78}$

A disputa entre o juiz e o comandante das milícias demonstra a perda de poder do primeiro, que tem que utilizar toda a sorte de estratagema para manter algum controle sobre os Ligeiros. Também é significativo o recurso do oficial de milícias a um processo, algo aparentemente comum nos conflitos entre esses homens e autoridades civis, o que nos faz acreditar que gozavam de prestígio suficiente para acreditar que seriam amparados por seus superiores nessas contendas.

\footnotetext{
${ }^{76}$ APEP, Códice 843, doc. 111, 24 de abril de 1827.

77 APEP, Códice 843, doc. 178 a 184.

${ }^{78}$ APEP, Códice 843, doc. 82 a 90. 
O ECLIPSE do PRINCIPAL: APONTAMENTOS SOBRE AS MUdANÇAS DE HIERARQUias ENTRE OS INDÍGENAS DO Gráo-Pará e os impactos no CONTROLE da SUA Mão de obra (DÉCADAS DE I 820 E I 830 )

Contudo, ainda mais revelador sobre os conflitos entre as autoridades pelo controle da mão de obra dos índios ligeiros, bem como a extensão da sua utilização, é a longa sequência de cartas entre o juiz de fora José dos Santos Silveira Souto e o comandante das Milícias de Ligeiros de Cametá Domingos Simôes da Cunha. De fato, são páginas e páginas de cópias de cartas entre os dois que foram enviadas ao Governador de Armas e posteriormente remetidas ao presidente para proteger as posiçóes do comandante militar na sua longa querela com o juiz. Após vários enfrentamentos entre os dois por diversos motivos - como a punição de escravos pelo comandante em lugares públicos sem consentimento do juiz ${ }^{79}$ - Domingos Cunha já havia negado o pedido do juiz para ceder três ligeiros para um trabalho particular. Pouco tempo depois, o juiz repetiu um pedido semelhante, mas agora solicitava cinco ligeiros que deveriam levar seu escriváo — provavelmente como remeiros — para outra parte da província, levando documentos produzidos pelo juiz. A resposta foi negativa, mas protocolar: o comandante dizia que não poderia dispor de cinco ligeiros, pois os que estavam ali aguardavam que as diligências trouxessem o restante para completar o número necessário de trabalhadores para o envio para as "fábricas nacionais" e o arsenal. Utilizava a deserção para justificar a negativa, dizendo que estavam tendo dificuldades para conseguir os trabalhadores necessários. Assim como aparece em correspondências de outros oficiais, Cunha ressalta que era obrigado a dar um determinado número de trabalhadores a esses serviços públicos, o que, a julgar pela recorrência de citaçôes, era uma enorme pressão sobre essas autoridades.

A troca de correspondência começa a ser mais relevante justamente porque os dois lados sobem o tom. Bastante agressivo, o juiz questiona Domingos da Cunha, dizendo que havia muitos ligeiros empatados sob o seu domínio há algum tempo e que sabia que eles não estavam destinados a serviços públicos e sim a trabalhar para particulares. Insistindo que os ligeiros náo eram militares propriamente ditos, insinuava que Cunha trazia para si uma prerrogativa que não tinha, pois esses indígenas não poderiam ser seu monopólio. $\mathrm{O}$ comandante militar responde no mesmo nível de agressividade, dizendo que durante todo o tempo em que estiveram em seu poder, os ligeiros foram empregados na construção de estradas e benfeitorias em prédios públicos. Também afirmava que, com a demora para conseguir alcançar o número de ligeiros através das diligências, tinha decidido enviar para as fábricas nacionais todos os que estivessem em seu controle.

O ponto central, no entanto, é que Cunha acusa o juiz de insinuar que estaria utilizando os indígenas em benefício próprio. É justamente a partir daí que é possível compreender melhor o mecanismo de controle das Milícias de Ligeiros e o possível benefício alcançado por seus comandantes. Domingos Simóes da Cunha bradava que não tinha em Cametá nenhum estabelecimento "nem de molhados, nem de lojas e tabernas, nem de canoas de negócios, nem de pescadores, nem de fabricar prédios ou consertar casas, estas ou quaisquer

\footnotetext{
${ }^{79}$ APEP, Códice 844, doc. 150 a 152.
} 
O ECLIPSE do PRINCIPAL: APONTAMENTOS SOBRE AS MUdANÇAS DE HIERARQUias ENTRE OS INDÍGENAS DO

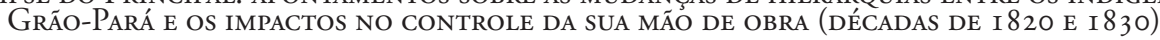

outras fábricas ou manufaturas", dizendo ainda que era escrupuloso em atender todas as suas necessidades por seus escravos, justamente para que não se pudesse falar que tirava proveito dos ligeiros. No entanto, o aspecto revelador da carta está no fato de que Cunha afirmava ter essa posição por uma atitude pessoal, mas que a lei facultava a ele, como comandante de milícias sem recebimento de salários, ter o privilégio de se utilizar dos ligeiros em qualquer uma das atividades mencionadas, só necessitando respeitar o pagamento dos jornais. ${ }^{80}$

Se a carta do comandante Domingos da Cunha, por um lado, ajuda a vislumbrar a extensão de atividades a que os ligeiros poderiam ser submetidos, o segundo aspecto que chama a atenção é o fato de afirmar que os comandantes dessa milícia poderiam usufruir desses braços para as mais diversas atividades. Tendo em mente o quadro mencionado, da enorme dependência e conflito pela mão de obra dos ligeiros, esse privilégio dos comandantes indica uma grande vantagem econômica e política. Em sua dissertação de mestrado, José Alves de Souza Jr. chama a atenção para o fato de que muitos dos que detinham poder econômico na província eram oficiais militares, tinham parentesco ou descendência desse meio. ${ }^{81} \mathrm{~A}$ possibilidade do controle da mão de obra dos indígenas avilados parece ser a razão mais lógica para essa concentração de poder entre os militares.

O fato é que o prestígio dos comandantes das Milícias de Ligeiros parece aumentar ao longo desse período. Como dito, os já citados processos desses comandantes contra outras autoridades da província, como juízes e padres, demonstram a confiança desses militares de que seriam protegidos pelo governador de armas e até pela presidência em suas querelas. $\mathrm{Na}$ mesma direção, no Arquivo Nacional é possível encontrar alguns processos de oficiais desse corpo, em 1826, pedindo condecoraçóes ou o hábito da Ordem de Cristo, numa demonstração que esses homens tentavam se nobilitar. ${ }^{82}$

O fato é que os comandantes das Milícias de Ligeiros eram cada vez mais figuras de peso na política paraense e frequentemente identificados como o maior obstáculo para os grupos que pretendiam mudanças mais radicais na província. Nesse sentido é que se pode entender as propostas para acabar com os comandantes militares de distrito - envolvidos no controle dos indígenas - e a já citada tentativa de retirar do poder militar a submissão dos ligeiros, duas iniciativas do Cônego Batista Campos, um conhecido liberal, já na primeira legislatura do Conselho Geral de Província. ${ }^{83}$ É certo que uma razóes para esse empenho estava em enfraquecer os comandantes de Milícias de Ligeiros.

O papel central dos comandantes de milícias de ligeiros na política da província e a sua ligação com os grupos mais conservadores pode ser percebido tanto pelas acusaçóes que

\footnotetext{
${ }^{80}$ APEP, Códice 844, doc. 157 a 161.

${ }^{81}$ SOUZA JR., José Alves. Constituição ou revolução: os projetos políticos para a emancipação do Grão-Pará e a atuação política de Filipe Patroni (1820/23). Dissertaçáo (Mestrado) — Unicamp, Campinas, 1997, p. 13-85. ${ }^{82}$ AN - IJJ9 - 106 - Ministério do Reino e do Império. Pará. Correspondência do Presidente da província (1820-26), doc. 282, 5 de fevereiro de 1826; AN - IJJ9 - 107 - Ministério do Reino e do Império. Pará. Correspondência do Presidente da Província (1826-28), doc. 69, 3 de outubro de 1826.

${ }^{83}$ APEP, Códice 889. Atas do Conselho Geral de Província, sessões de 8 e 19 de fevereiro de 1830.
} 
O ECLIPSE do PRINCIPAL: APONTAMENTOS SOBRE AS MUdANÇAS DE HIERARQUias ENTRE OS INDÍGENAS DO Gráo-Pará e os impactos no CONTROLE da SUA Mão de obra (DÉCADAS DE I 820 E I 830 )

eram feitas como pelas tentativas de aliança que a esses homens eram oferecidas. Como mencionado antes, esses oficiais estiveram entre os principais militares que deram apoio à permanência de José Maria de Moura. Por sua vez, Batista Campos utilizou os seus jornais para acusar os comandantes das Milícias de Ligeiros pelo golpe que depôs o Visconde de Goiana da presidência da província, em 1831, e resultou na perseguição de todos os homens que eram identificados como liberais radicais. ${ }^{84}$

Do outro lado, dois meses antes da eclosão da Cabanagem, quando a escalada de conflitos políticos e mesmos de açôes militares já tinha atingido um patamar perigoso, publica-se no jornal do governo uma chamada convocando os oficiais da extinta Milícia de Ligeiros para reforçar a segurança da província. ${ }^{85}$ Por fim, quando a Cabanagem está sendo reprimida, a Assembleia Provincial aprova, em 1838, a lei do Corpo de Trabalhadores. Como percebeu Moreira Neto, tratava-se de uma estrutura muito parecida com a Milícia de Ligeiros, obrigando agora não só aos indígenas, mas a todos os não brancos que não pudessem comprovar uma ocupação fixa a trabalhar em serviços públicos e particulares, tendo até a sua livre circulação controlada. A similitude entre as duas instituições não estava apenas no seu funcionamento e objetivos: a lei expressamente determinava que o controle sobre esses trabalhadores deveria ser entregue justamente aos antigos oficiais da Milícia de Ligeiros. ${ }^{86}$ Com isso ficava explícito o poder político desses comandantes militares e a sua aliança com os grupos mais conservadores da província.

Esse novo cenário das décadas de 1820 e 1830 no Grão-Pará, aqui descrito, demonstra que os desdobramentos da Carta Régia de 1798 modificaram substancialmente a organização das sociedades indígenas a partir de um elemento-chave: a exploração do trabalho compulsório. O fortalecimento do Oficial de Milícia de Ligeiros como peça-chave dessa atividade retirou cada vez mais o controle das sociedades indígenas sobre a sua força de trabalho. Somado a isso, as descriçôes dos recrutamentos cada vez mais semelhantes às caçadas sugerem comunidades indígenas mais frágeis. A possibilidade de os oficiais de Milícia de Ligeiros serem também os Principais parece remota, ou restrita. As associaçôes políticas já descritas entre os oficiais e os grupos mais conservadores da província, claramente ligados à exploração compulsória do trabalho indígena, tornam difícil essa hipótese. Ainda que uma das fontes de poder dos Principais durante o governo português fosse a exploração compulsória de outros indígenas, como visto no Diretório, parece pouco provável a larga ocupação desse posto por essas lideranças. Afinal de contas, em toda a documentação os oficiais de Ligeiros sempre estáo vinculados a uma radical exploração compulsória dos indígenas, sem nunca protagonizarem qualquer ação em favor da garantia de direitos desses indivíduos, característica que sempre se impôs a esse tipo de liderança como forma de preservar sua autoridade.

\footnotetext{
${ }^{84}$ AIHGB PER 32.14 - O Publicador Amazoniense. Ediçóes de 12 de janeiro de 1833.

${ }^{85}$ AIHGB - PER 27.12 - Correio Oficial Paraense. Edição de 15 de novembro de 1834.

${ }^{86}$ AIHGB - Lata 415, pasta 8 - Coleção das leis provinciais do Pará promulgadas na primeira secção que teve princípio no dia 02 de março e findou no dia 15 de maio de 1838. Tipografia Restaurada, 1838.
} 
O ECLIPSE do PRINCIPAL: APONTAMENTOS SOBRE AS MUdANÇAS DE HIERARQUias ENTRE OS INDÍGENAS DO Gráo-Pará e os impactos no CONTROLE da SUA Mão de obra (DÉCADAS DE I 820 E I 830 )

Nesta direção, parece mais plausível a presença de antigas lideranças indígenas nas câmaras municipais. Afinal, como se verá a seguir, as câmaras tinham essa dupla atuação: ao mesmo tempo que se notabilizam por absorver e reivindicar braços indígenas, elas também registram ações que buscam preservar direitos desses indivíduos, entre elas a denúncia de não observância de isençôes no recrutamento para milícia de ligeiros.

\section{As Câmaras Municipais: o jogo complexo do controle da mão de obra indígena}

Por ocasião da apresentação de uma versão preliminar deste artigo, ${ }^{87}$ uma questão foi várias vezes apresentada pelos debatedores do simpósio: as antigas lideranças indígenas, entre elas o Principal, náo teriam encontrado em postos das câmaras o lugar para exercer o seu protagonismo nessas comunidades? Em todo momento ficou claro que esta era uma suposiçáo, sem que os outros pesquisadores tivessem demonstraçôes empíricas desse processo em outras regióes do império.

Esta é uma questão tão importante quanto difícil de responder. A maior dificuldade, sem dúvida alguma, está na impossibilidade de consultar a documentação própria das câmaras, sobretudo as atas. No Arquivo Público do Pará não há códices específicos para as câmaras. Assim como no Arquivo Nacional, o que se encontra disponível no Pará são correspondências entre as câmaras e outras autoridades. Com a reforma do Instituto Histórico e Geográfico do Pará e a posterior disponibilização do seu acervo, há expectativa de se localizar algumas atas das câmaras, pelo menos as referentes a Belém.

A partir das correspondências das câmaras, não resta dúvida de que temos conclusóes limitadas. Mas há alguns apontamentos que ajudam a cercar o problema ainda que de forma não definitiva. Por exemplo, não resta dúvida de que os indígenas estavam presentes nas câmaras. Por exemplo, uma das justificativas do governo do Pará para a demora nas eleiçôes dos deputados para a Cortes de Lisboa, no começo da década de 1820, era o fato de que alguns cargos de juízes no interior eram ocupados por indígenas, tidos como inabilitados para a função. ${ }^{88}$ Mais tarde, em 1828, a Câmara da Vila de Oeiras escrevia uma carta ao presidente da província, queixando-se sutilmente dos oficiais locais que obrigavam os vereadores, entáo um miliciano e dois milicianos ligeiros, a algumas açóes em que estavam subordinados a estas autoridades. A queixa contra um oficial deixa inequívoco que eram ligeiros comuns e, portanto, indígenas. ${ }^{89}$ Com esses dados sabe-se que os indígenas, de fato, ocupavam cargos na vilas, como estava previsto no Diretório e na Carta Régia de 1798. No entanto, ainda não é possível saber o tamanho dessa representação política e se isso revertia em um real controle dos indígenas sobre a política na vilas e, sobretudo, sobre a distribuição da sua mão de obra.

\footnotetext{
${ }^{87}$ Durante o 27ํㅡㄹ Encontro Nacional de História, em 2015.

${ }^{88}$ AHU - ACL - CU 013, cx. 150, doc. 11.616.

${ }^{89}$ APEP, Códice 857, doc. 14.
} 
O ECLIPSE do PRINCIPAL: APONTAMENTOS SOBRE AS MUdANÇAS DE HIERARQUias ENTRE OS INDÍGENAS DO Gráo-Pará e os impactos no CONTROLE da SUA Mão de obra (DÉCADAS DE I 820 E I 830 )

Outra questão que é patente nos documentos é que as Câmaras requisitavam frequentemente a mão de obra dos indígenas para diversos trabalhos. Exemplo disso está nas atas do Conselho Geral de Província de 1831, quando chega a este órgão uma série de pedidos de câmaras do interior para que fossem enviados indígenas para cumprir diversos trabalhos nas vilas. ${ }^{90}$ Aliás, essas correspondências são curiosas por deixar claro que as câmaras escolheram o Conselho Geral de Província para solicitar envio de mão de obra indígena, o que a princípio pode parecer um absurdo. Afinal, o controle sobre essa mão de obra não era da própria câmara a partir dos juízes? Ou dos oficiais de Milícias Ligeiros? Se nessas correspondências as câmaras recorrem ao Conselho Geral de Província para solicitar o envio de mão de obra indígena, há outra série ofícios das câmaras fazendo o mesmo tipo de pedido, só que escolhendo o presidente da província como destinatário. Assim, em 1828, a Câmara de Macapá escreve uma carta pedindo ao presidente o envio de milicianos ligeiros para fazer reparos na própria casa da câmara, descrita como em estado deplorável. ${ }^{91}$

Por que o envio desse tipo de pedido para o presidente? Talvez para as câmaras, nesse período pouco posterior à independência, o papel do presidente ainda estivesse associado a um poder quase absoluto dos capitães-gerais. Exemplo disso é o excesso de elogios feitos ao presidente no mesmo período por outra câmara que fazia questão de identificar esse posto como o de "lugar-tenente" do próprio soberano. ${ }^{92}$ Outra explicação possível está em uma outra correspondência, enviada pela Câmara de Gurupá: essa carta, que retomaremos a seguir, foi ditada pelos autointitulados "moradores índios de Gurupá” e entre as suas afirmaçóes, dizia que esse período, o final da década de 1820, era o pior desde o tempo do Diretório, pois não estava claro quem governava os indígenas nas suas funçôes de milicianos ligeiros. ${ }^{93}$ Essa correspondência exemplifica o que tentamos discorrer desde o começo do texto: no início do século XIX, há uma grande sobreposição de autoridades e de papéis no controle da mão de obra dos indígenas no Pará. Isso gera um conjunto de tensôes e conflitos entre as autoridades que, entre outras coisas, parece ter sido uma das responsáveis pelo aumento do poder dos oficiais de milícias de ligeiros para além do que estava previsto originalmente na Carta Régia de 1798. Mesmo, assim, nem essa autoridade tinha assegurado o seu poder sobre essa questáo, restando vários ofícios destinados aos presidentes e aos governadores de armas, mirando essas altas autoridades como árbitros do controle dessa mão de obra.

Isso não quer dizer que, ao tratar dos indígenas, as correspondências das câmaras para os presidentes fossem sempre dóceis. Ao contrário, em algumas delas as câmaras deixam explícito que entendem que os seus direitos sobre esses braços estão sendo desrespeitados.

\footnotetext{
${ }^{90}$ APEP, Códice 889. Atas do Conselho Geral de Província, sessão de 1 de fevereiro de 1830; Arquivo Histórico da Câmara dos Deputados (AHCD) — Lata 68, maço 37, pasta 4 - Atas das sessóes do Conselho Geral do Pará. Sessóes de 6, 7 e 29 de dezembro de 1831.

${ }^{91}$ APEP, Códice 857, doc. 3.

${ }^{92}$ APEP, Códice 857, doc. 6.

${ }^{93}$ APEP, Códice 857, doc. 67.
} 
O ECLIPSE do PRINCIPAL: APONTAMENTOS SOBRE AS MUdANÇAS DE HIERARQUias ENTRE OS INDÍGENAS DO Gráo-Pará e os impactos no CONTROLE da SUA Mão de obra (DÉCADAS DE I 820 E I 830 )

Em 1828, a Câmara de Alenquer deixa isso cristalino: ao se dirigir ao presidente, a câmara tem um tom respeitoso, mas ao mesmo tempo duro. Reclama que 17 Ligeiros tinham sido retirados da vila para trabalhar no Arsenal da Marinha, desconsiderando-se que a câmara também tinha suas necessidades. Aí passa a reclamar do pouco número de indígenas que dispunha, descrevendo que esses estavam envolvidos até na cobrança de tributos como o dízimo. Pede, enfaticamente, que os Ligeiros sejam devolvidos, argumentando que, caso contrário, esses provavelmente também desertariam ao fim dos trabalhos. A fuga dos indígenas, geralmente para o Rio Negro, abandonando suas antigas famílias, era recorrente, segundo a câmara, e uma das razóes do despovoamento de Alenquer. ${ }^{94}$

Contudo, uma das questôes que tornam a atuação das Câmara complexa é que ao mesmo tempo que a documentação deixa claro que essa era uma das instituiçóes que mais absorviam esses braços, eram também espaços que cobravam a observação do direito dos indígenas, inclusive no tocante ao uso da sua mão de obra. Exemplo disso, em 1831 a Câmara de Santarém enviava ao Conselho Geral de Província uma carta na qual reclamava que os índios que estavam na condiçâo de milicianos Ligeiros sofriam uma série de constrangimentos e de abusos, tanto nos trabalhos públicos como nos particulares. A leitura da carta criou discussão entre os conselheiros, entre aqueles que apoiavam um parecer vago sobre as denúncias e aqueles que desejavam medidas mais efetivas. Por fim, prevaleceu o silêncio do Conselho Geral. ${ }^{95}$ É interessante perceber, no entanto, que a ausência de providências não intimidou os moradores de Santarém: no ano legislativo seguinte, em 22 de dezembro de 1831, lia-se uma nova representação que agora reclamava dos Comandantes Militares de Distrito, dizendo que esses não permitiam que os habitantes gozassem dos direitos da Constituição. Por meio do debate do período, sabe-se que o problema relacionado com esses comandantes de distrito era exatamente o controle da mão de obra dos tapuios, o que significa que as duas representaçôes reclamavam do mesmo problema. No entanto, a segunda é mais significativa pela utilizaçáo de um discurso mais próximo dos liberais: não se reclamava apenas do desvio ou do exagero de alguns funcionários, mas se alertava que essa instituição impedia o livre exercício de direitos constitucionais. Era, portanto, a reclamação de cidadãos. ${ }^{96}$

Há outros exemplos em que as câmaras protagonizaram a defesa de direitos dos indígenas. Em 1828, a Câmara de Belém escreveu ao presidente contra uma ação que entendia ser uma arbitrariedade no recrutamento dos indígenas. No caso, a câmara explicava que há alguns anos concedera a todos os pescadores da cidade um diploma que os isentava do recrutamento para qualquer trabalho público. Os vereadores de Belém explicavam que essa era uma ação necessária para garantir o abastecimento da cidade com pescados. No entanto,

\footnotetext{
${ }^{94}$ APEP, Códice 857, doc. 38.

${ }^{95}$ Biblioteca Nacional (BN) - MS — 602 (1), doc. 17. Atas das sessôes do Conselho Geral do Pará de 15 de dezembro de 1830 a 28 de fevereiro de 1831 . Sessão de 28 de fevereiro de 1831.

${ }^{96}$ AHCD - Lata 68, maço 37, pasta 4 - Atas das sessões do Conselho Geral do Pará. Sessão de 22 de dezembro de 1831 .
} 
O ECLIPSE do PRINCIPAL: APONTAMENTOS SOBRE AS MUdANÇAS DE HIERARQUias ENTRE OS INDÍGENAS DO Gráo-Pará e os impactos no CONTROLE da SUA Mão de obra (DÉCADAS DE I 820 E I 830 )

a câmara queixava-se que essa isenção do recrutamento não estava sendo respeitada pelo oficial de milícia de Ligeiros, que já havia avisado que dois indígenas pescadores seriam alistados nessas milícias, mesmo após esses indivíduos terem mostrado seus diplomas de isenção. O discurso da câmara é a radical defesa do direito de isenção desses indígenas em relação ao trabalho compulsório. ${ }^{97}$

No entanto, em outras ocasióes as câmaras encaminharam demandas dos indígenas das vilas, mas claramente a contragosto. Esse é o caso da já citada carta da Câmara de Gurupá ao presidente da província, em 1828. Como já foi mencionado, a correspondência foi ditada por indivíduos que se identificavam como os "moradores índios da vila de Gurupá” que prestavam serviços como milicianos Ligeiros. Em resumo, a queixa encaminhada dizia respeito a uma série de açóes entendidas pelos ligeiros como abusivas, entre elas o recrutamento por oficiais de outras vilas. A câmara encaminhou a carta ao presidente, mas em anexo fazia esclarecimentos de que tinha sido forçada a isso. Nessa direção, diz que na vila poucos são alfabetizados e que os reclamantes teriam forçado o escrivão do juiz a escrever a carta que seria posteriormente enviada. ${ }^{98}$

Ainda mais radicalmente contrário à posição dos indígenas foi o embate entre a Câmara de Belém e os operários do Arsenal da Marinha, pouco depois do alinhamento do Pará às Cortes Portuguesas, em 1821. O Arsenal da Marinha, como já mencionado, era um lugar que demandava muita mão de obra dos índios avilados por meio do recrutamento compulsório. Sob a liderança de Valentim José, esses operários exigiram a demissão do Intendente do Arsenal, João Antonio Rodrigues Martins, sob a alegação de que seus maus-tratos aos trabalhadores o faziam um déspota. Utilizando largamente o vocabulário liberal, os operários buscavam ligar Martins ao regime deposto. Contudo, apesar da imensa pressão e insistência dos operários, a câmara apenas comunicou a reivindicação à Junta de Governo. Com a negativa da junta, a câmara exigiu que a reclamação fosse apresentada por escrito, o que foi compreendida pelos operários como uma forma de obrigá-los a desistir do assunto, já que a cultura letrada era restrita. $\mathrm{O}$ passo seguinte é o essencial: os operários entendem que a câmara e a junta não atenderão o seu pedido e escrevem a reclamação diretamente para as Cortes de Lisboa. Em meio a tamanha pressão, não coube outro recurso ao intendente a não ser renunciar. ${ }^{99}$

Todos esses exemplos deixam claro que a composição das câmaras e o seu alinhamento em relação à exploração do trabalho compulsório dos indígenas não era uniforme. Havia indígenas em seus quadros, mas nada indica que esse fosse o grupo predominante. Da mesma forma, se há ações de defesa dos direitos dos indígenas através das câmaras, também há movimentos que visam bloquear essas reivindicações. Dessa forma, mesmo que lideranças indígenas tenham ocupado esses cargos nas décadas de 1820 e 1830, parece evidente que

\footnotetext{
${ }^{97}$ APEP, Códice 857, doc. 56.

${ }^{98}$ APEP, Códice 857, doc. 67.

${ }^{99}$ AHU, ACL, CU 013, cx. 151, docs. 11.654 e 11.644 
O ECLIPSE do PRINCIPAL: APONTAMENTOS SOBRE AS MUdANÇAS DE HIERARQUiAS ENTRE OS INDÍGENAS DO Gráo-Pará e os impactos no CONTROLE da SUA Mão de obra (DÉCADAS DE I 820 E I 830 )

André Roberto de Arruda Machado

isso não garantiu a esses homens o poder de coesão das sociedades indígenas que era possível aos Principais até a lei de 1798.

\section{Considerações finais}

O "eclipse" dos Principais, ou seja, o quase desaparecimento nas fontes de citaçóes dessas lideranças indígenas nas décadas de 1820 e 1840 no Pará não é obra do acaso. Ao contrário, sintetiza uma sociedade em mudança. Ao longo das páginas anteriores, buscou-se demonstrar que a lei de 1798 realmente produziu mudanças muito significativas no controle da mão de obra e na própria organização das sociedades indígenas do Pará. A perda dos atributos do Principal no estabelecimento de novas povoaçôes, através dos descimentos, assim como na distribuição de mão de obra, teve significativo peso nas alteraçôes de hierarquias desses grupos. Mesmo que algumas lideranças tenham encontrado outras posiçóes de mando, como as câmaras ou eventualmente os postos de oficiais de milícias, o artigo buscou demonstrar que isso não se deu de forma coesa, homogênea. Até agora, a documentação só evidencia casos pontuais e não uma regra de funcionamento desses postos.

Com o enfraquecimento das comunidades em torno das lideranças, isso significou que as identidades indígenas partiram para um processo de individualização, como sugeriram alguns autores? A barreira entre os indígenas e os não indígenas teria diminuído? Em vários momentos, o artigo demonstra que não. Esses homens continuam a se identificar como indígenas e assim são vistos pelo Estado. Nessa direção, a condição de homens obrigados ao trabalho compulsório era uma marca de diferenciação que a todo momento recolocava para esses homens a sua condição de indígenas. $\mathrm{O}$ trabalho, mais uma vez, é uma questão central para se compreender a história dos indígenas no século XIX.

\section{Fontes}

BAENA, Antonio Ladislau Monteiro. Ensaio corográfico sobre a província do Grão-Pará. Pará: Typographia de Santos \& Menor, 1839.

BAENA, Antonio Ladislau Monteiro. Representação ao Conselho Geral da Província do Pará sobre a especial necessidade de um novo regulamento promotor da civilização dos índios da mesma província. In: Arquivo Público do Estado do Pará (APEP). Anais da Biblioteca e Arquivo Público do Pará. Tomo 2, Belém: Imprensa Oficial, 1902.

CARTA RÉGIA DE 1798 (e esclarecimentos sobre a sua aplicação). In: MOREIRA NETO, Carlos de Araújo. Indios da Amazônia: de maioria a minoria (1750-1850). Petrópolis: Vozes, 1988. 
O ECLIPSE do PRINCIPAL: APONTAMENTOS SOBRE AS MUdANÇAS DE HIERARQUiAS ENTRE OS INDÍGENAS DO

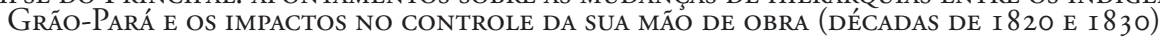

DIRETÓRIO que se deve observar nas povoaçôes dos índios do Pará e Maranhão enquanto sua majestade não mandar o contrário. Lisboa, Oficinal de Miguel Rodrigues, 1758.

FLORENCE, Hércules. Viagem fluvial do Tietê ao Amazonas de 1825 a 1829. Brasília: Senado Federal, 2007.

SPIX, Johann B. von; MARTIUS, Karl Friedrich P. von. Viagem pelo Brasil, 1817-1820. Trad. Lúcia Furquim Lahmeyer. Belo Horizonte: Editora Itatiaia; São Paulo: Editora da Universidade de São Paulo, 1981. V. III.

ZANY, José Ricardo. Projeto para os índios do Grão-Pará. In: Diário das Cortes, 1821/1822. Sessáo de 26 de agosto de 1822. Disponível em: <http://debates.parlamento.pt>.

Arquivo Público do Estado do Pará (APEP). Códices 713, 869, 742, 754, 843, 844, 857, 889.

Arquivo Histórico Ultramarino (AHU). Caixas 150, 151, 155.

Arquivo Nacional (AN). IJJ9 - 106 - Ministério do Reino e do Império. Pará. Correspondência do Presidente da província (1820-26); AN. IJJ9 - 107 - Ministério do Reino e do Império. Pará. Correspondência do Presidente da Província (1826-28).

Arquivo do Instituto Histórico e Geográfico Brasileiro (AIHGB). PER 32.14 - O Publicador Amazoniense; AIHGB. PER 27.12 - Correio Oficial Paraense; AIHGB. Lata 415, pasta 8 Coleção das leis provinciais do Pará promulgadas na primeira secção que teve princípio no dia 02 de março e findou no dia 15 de maio de 1838. Tipografia Restaurada, 1838.

Arquivo Histórico da Câmara dos Deputados (AHCD). Lata 68, maço 37, pasta 4 - Atas das sessões do Conselho Geral do Pará.

Biblioteca Nacional (BN). MS - 602 (1), doc. 17. Atas das sessóes do Conselho Geral do Pará de 15 de dezembro de 1830 a 28 de fevereiro de 1831

\section{Bibliografia citada}

ALENCASTRO, Luiz Felipe de. O trato dos viventes. Formação do Brasil no Atlântico Sul. Sáo Paulo: Companhia das Letras, 2000.

ALMEIDA, Maria Regina Celestino de. Metamorfoses indigenas: identidade e cultura nas aldeias coloniais do Rio de Janeiro. Rio de Janeiro: Arquivo Nacional, 2001.

BELLOTO, Heloísa Liberalli. Política indigenista no Brasil Colonial (1570-1757). Revista do Instituto de Estudos Brasileiros, São Paulo, n. 29, 1988.

BRITTO, Michelle Carolina de. O Diretório Pombalino e os índios no Grão-Pará setecentista (1750-1798). Monografia de fim de curso - Unifesp, Guarulhos, 2014. 
O ECLIPSE do PRINCIPAL: APONTAMENTOS SOBRE AS MUdANÇAS DE HIERARQUiAS ENTRE OS INDÍGENAS DO

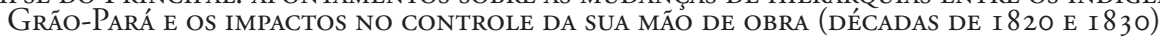

CLEARY, David. Lost Altogether to the Civilised World: Race and Cabanagem in Northern Brazil, 1750 to 1850. Comparative Studies in Society and History, v. 40, n.1, p. 109-135, 1998. COELHO, Geraldo Mártires. Anarquistas, demagogos e dissidentes: a imprensa liberal no Pará de 1822. Belém: CEJUP, 1993.

COELHO, Mauro Cezar. Do sertão para o mar: um estudo sobre a experiência portuguesa na América, a partir da colônia: o caso do Diretório dos Índios (1750-98). Tese (Doutorado) — USP, São Paulo, 2005.

DOMINGUES, Ângela. Quando os indios eram vassalos: colonização e relaçóes de poder no Norte do Brasil na segunda metade do século XVIII. Lisboa: Comissão Nacional para as comemoraçôes dos descobrimentos portugueses, 2000.

FARAGE, Nádia. As muralhas dos sertóes: os povos indígenas no Rio Branco e sua colonização. Rio de Janeiro: Paz e Terra, 1991.

FAUSTO, Carlos. Os índios antes do Brasil. 4. ed., Rio de Janeiro: Zahar, 2010.

FLORENCE, Hércules. Viagem Aluvial do Tietê ao Amazonas de 1825 a 1829. Brasília: Senado Federal, 2007.

FREIRE, José Ribamar Bessa. Rio Babel: a história das línguas na Amazônia. Rio de Janeiro: Eduerj, 2004.

HARRIS, Mark. Rebellion on the Amazon: the Cabanagem, Race, and popular culture in the North of Brazil, 1798-1840. Nova York: Cambridge University Press, 2010.

MACHADO, André Roberto de A. A quebra da mola real das sociedades: a crise política do Antigo Regime Português na província do Grão-Pará (1821-25). São Paulo: Hucitec, 2010.

- O Conselho Geral da Província do Pará e a definição da política indigenista no Império do Brasil (1829-31). Almanack, v. 10, p. 181-237, 2015.

. O fiel da balança: o papel do parlamento brasileiro nos desdobramentos do golpe de 1831 no Grão-Pará. Revista de História (USP), São Paulo, n. 164, 2011.

MONTEIRO, John Manuel. Os negros da terra: índios e bandeirantes nas origens de São Paulo. São Paulo: Companhia das Letras, 1994.

MOREIRA, Vânia Maria Losada. A serviço do império e da nação: trabalho indígena e fronteiras étnicas no Espírito Santo (1822-60). Anos 90, v. 17, n. 31, 2010.

MOREIRA, Vânia Maria Losada. Indios e império: direitos sociais e agenciamento indígena. Anais da Anpuh, ST 36, 2009.

MOREIRA NETO, Carlos de Araújo. Índios da Amazônia: de maioria a minoria (17501850). Petrópolis: Vozes, 1988.

NOGUEIRA, Shirley Maria Silva. Razóes para desertar: institucionalização do exército no Estado do Grão-Pará no último quartel do século XXVIII. Dissertação (Mestrado) NAEA/UFPA, Belém, 2000. 
O ECLIPSE do PRINCIPAL: APONTAMENTOS SOBRE AS MUdANÇAS DE HIERARQUias ENTRE OS INDÍGENAS DO

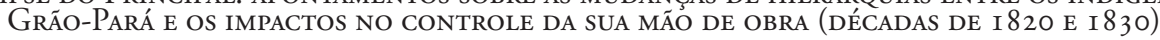

André Roberto de Arruda Machado

PERRONE-MOISÉS, Beatriz; SZTUTMAN, Renato. Notícias de uma certa confederação tamoio. Mana, v. 16, n. 2, p. 401-433, 2010.

ROCHA, Rafael Ale. Os oficiais índios na Amazônia pombalina: sociedade, hierarquia e resistência (1751-1798). Dissertação (Mestrado) - UFF, Niterói, 2009.

SAMPAIO, Patrícia Melo. Espelhos partidos: etnia, legislação e desigualdade na colônia. Manaus: EDUA, 2012.

. "Vossa Excelência mandará o que for servido"...: políticas indígenas e indigenistas na Amazônia Portuguesa do final do século XVIII. Tempo, n. 23, p. 9-55, 2007.

SOUZA JR., José Alves. Constituição ou revoluçâo: os projetos políticos para a emancipação do Gráo-Pará e a atuaçáo política de Filipe Patroni (1820/23). Dissertaçáo (Mestrado) Unicamp, Campinas, 1997. 